Monografias Ambientais

(e-ISSN: 2236-1308)

REMOANFSM

\title{
POTENCIAL ECOTURÍSTICO DO MUNICÍPIO DE AGUDO-RS
}

\author{
Marlisa Marlene Strenzel ${ }^{1}$, Elisane Maria Rampelotto² \\ ${ }^{1}$ Autora, Especialista em Educação Ambiental pela UFSM. \\ 2 Orientadora - Curso de Especialização em Educação Ambiental - UFSM
}

\section{RESUMO}

Este trabalho aborda o tema do ecoturismo no município de Agudo-RS, Brasil, que constitui uma de suas maiores vocações, em decorrência dos seus variados atrativos naturais.

O município de Agudo apresenta um potencial ecoturístico notável, identificado desde o morro que Ihe origina o nome, morros com penhascos utilizados para a prática de esportes radicais, cascatas, quedas d'água, balneários, trilhas no interior da mata atlântica, biodiversidade com fauna e flora notáveis e jazimentos fósseis raros de eras geológicas passadas.

Entretanto, pelo exame dos documentos existentes e da realidade atual do turismo no município, verifica-se que existe uma deficiência na sua efetiva implementação por parte do poder público municipal. Este fato implica também na incapacidade estrutural da iniciativa privada em estabelecer produtos ecoturísticos viáveis e sustentáveis.

Com o objetivo de fornecer uma significativa contribuição para a retomada do ecoturismo no município foram elaborados o "Mapa Ecoturístico do Município de Agudo", o diagnóstico do potencial turístico do município, o levantamento das atuais práticas de ecoturismo e de esportes de natureza nele existentes, uma proposta de "Código de Conduta dos Ecoturistas em Agudo" e estabelecidas conclusões e recomendações passíveis de apropriação para a formulação de intervenções sistemáticas e continuadas por parte dos gestores públicos.

Palavras-chave: turismo; ecoturismo; turismo ecológico; município de Agudo; Rio Grande do Sul; Brasil.

\section{ABSTRACT}

This work seeks to make an approach to the ecotourism in Agudo, RS, Brazil. Ecotourism is the major attraction of the municipality, given its rich natural resources.

The municipality of Agudo offers a notable potential for ecotourism, starting from the hill it was named after, cliffs that are used for the practice of extreme sports, waterfalls, bathing resorts, trails in inner Mata Atlântica, biodiversity with remarkable fauna and flora, as well as deposits of rare fossils dating back to past geological eras.

However, according to the inspection of the available documents and the current reality of the area, we have noticed a shortcoming in the effective implementation of tourism by the local government. This situation also reflects the inability of private institutions to establish viable and sustainable products.

Aiming at contributing to the resumption of ecotourism in the town, were created the "Ecoturistical Map of Agudo municipality", the diagnosis of the potential for tourism, the appreciation of the current ecotourism and natural sports activities, a proposal of "A Behaviour Code for the Ecotourists", and were drawn the conclusions and recommendations, subject to continuous and systematic appropriation from the local government.

Keywords: tourism; ecotourism; ecological tourism; Agudo municipality; Rio Grande do Sul State; Brazil.

\section{INTRODUÇÃO}

O ecoturismo é uma atividade que busca valorizar as premissas ambientais, sociais, culturais e econômicas e inclui a interpretação ambiental como um fator importante durante a experiência turística.

Os documentários em vídeo sobre viagens que apresentavam a natureza como cenário principal nos finais da década de 1970, foi sem dúvida, o grande impulsionador do turismo ecológico no mundo. No Brasil, o termo ecoturismo ganhou maior visibilidade com a ECO-92, a conferência realizada na cidade do Rio de Janeiro em 1992, estimulou um mercado promissor que desde então não pára de crescer. 
O município de Agudo situa-se na Depressão Central do Estado, fazendo parte da chamada Quarta Colônia, circundada por diversos morros, distante a 250 quilômetros de Porto Alegre, com uma área de $553,1 \mathrm{~km}^{2}$. Agudo possui altitude de 83 metros na sede, tendo como coordenadas geográficas $29^{\circ} 38^{\prime} 34^{\prime \prime}$ de latitude Sul e $53^{\circ} 14^{\prime} 58^{\prime \prime}$ de longitude Oeste, na entrada da sede da Prefeitura Municipal.

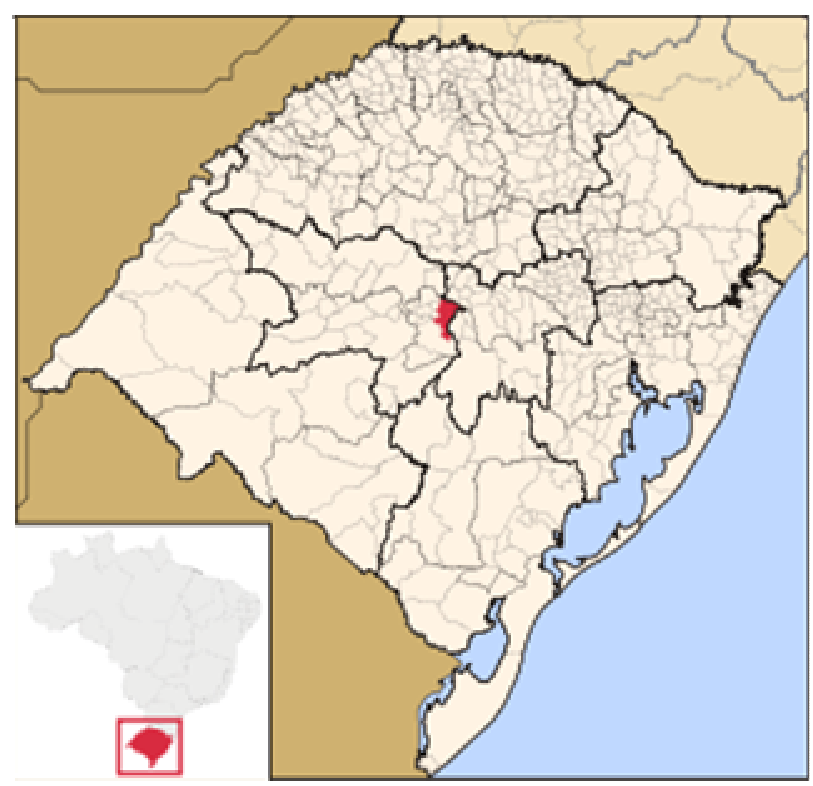

Figura 1 - Localização do município de Agudo no Estado do Rio Grande do Sul.

Fonte: Wikipédia, 2011.

Localizado na margem esquerda do Rio Jacuí, encostas da Serra Geral, o município tem lugar de destaque pelo padrão da comunidade, por sua tradição, vida e vontade de progredir, sem preconceitos de origens e sem imposições.

Agudo é caracterizado pela diversidade ambiental e pela paisagem rural composta por agricultores que trabalham em suas lavouras, campos, matas secundárias, formações de rochas entre outras belezas naturais e representações da cultura local.

A potencialidade ecoturística do município de Agudo é ampla em função do patrimônio natural, tais como paisagens, morros, cerros, arroios, rio, cascatas, caverna, flora e fauna, estando, porém, subutilizada. Agudo, atualmente, tem o turismo de aventura como um segmento do ecoturismo que possibilita o lazer inserido na natureza através de escaladas, rapel, trilhas, parapente e asa-delta.

O ecoturismo se bem planejado e desenvolvido pode trazer diversos benefícios ao município, como oportunidades de diversificação e consolidação econômica além de geração de empregos por que do ponto de vista mercadológico, o ecoturismo é um segmento que tem obtido um crescimento considerável ao longo dos últimos anos. A ampliação correta e sustentável do Ecoturismo deverá ser realizada a partir de embasamento originado da Educação Ambiental.

O município de Agudo participou - inicialmente - da Quarta Colônia como um elemento germânico exótico, juntamente com Restinga Seca, o elemento "campeiro" da região. Agudo, além do mais, constituía a saída geográfica da Quarta Colônia. A partir do trágico evento da queda da ponte da RSC 287 sobre o rio Jacuí, que separa o município de Agudo de Restinga Seca, na data de 5 de janeiro de 2010, esta situação se inverteu de forma definitiva, havendo a troca da polaridade turística de saída-entrada e colocando Agudo como a "porta de entrada" da Quarta Colônia (ver Figuras 2 e 3).

Esta nova situação potencializa ainda mais a entrada de Agudo em um regime de exploração intensivo do turismo e, de maneira muito especial, do ecoturismo. 


\section{Monografias Ambientais}

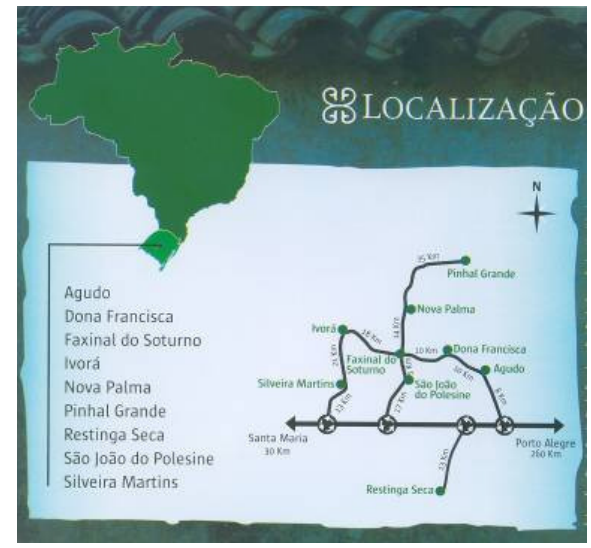

Figura 2 - Localização do município de Agudo como entrada da Quarta Colônia. Fonte: Folder da Quarta Colônia; Roteiros Integrados.

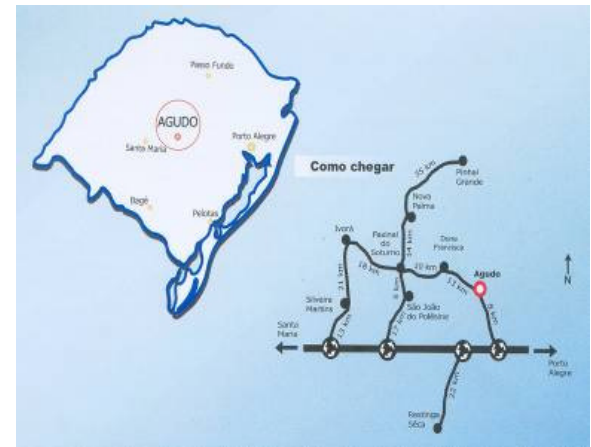

Figura 3 - Localização do município de Agudo no Estado do Rio Grande do Sul e na Quarta Colônia. Fonte: Calendário de Eventos 2010; Agudo/RS.

\section{OBJETIVOS}

Promover a aplicação da Educação Ambiental ao ecoturismo através da conscientização dos habitantes de Agudo sobre seu patrimônio ambiental e a necessidade de sua preservação visando à sustentabilidade e pelas informações corretas a serem divulgadas aos ecoturistas, visitantes e outros passantes quanto ao respeito e usufruto do patrimônio natural e cultural que lhes é apresentado. Além disso:

* sugerir ações baseadas na Educação Ambiental formal, nos seus diferentes níveis, de modo que proporcione a crianças, jovens e adultos, incluindo a terceira idade, uma conscientização diferenciada sobre a preservação ambiental e sustentabilidade de seu patrimônio que é a base do ecoturismo e do turismo;

* na Educação Ambiental informal, orientar os ecoturistas, turistas, viajantes e passantes quanto à percepção do patrimônio natural e cultural que é colocado à sua disposição;

* envolver e discutir com a comunidade local as atividades de ecoturismo e turismo sustentável;

* incentivar investimentos em conservação dos recursos culturais e naturais utilizados;

* fazer com que a conservação beneficie materialmente comunidades envolvidas, pois somente servindo de fonte de renda alternativa estas se tornarão aliadas de ações conservacionistas; 
* propor a construção da "Casa de Agudo" junto ao pórtico de entrada da cidade na RSC 287 para promover arranjos produtivos locais - APLs municipais;

* colocar Agudo como um Centro de Ecoturismo para potencializar as suas imensas belezas naturais, cênicas, rurais e culturais, utilizando o conceito de Educação Ambiental como vetor;

* criar e ampliar a rede municipal de trilhas ecológicas.

\section{MÉTODOS UTILIZADOS}

A metodologia de um estudo é definida como sendo a descrição, análise e avaliação crítica dos métodos de investigação, ou ainda, é o estudo de uma operação, do ponto de vista de seu modo de proceder (FACCHIN, 2001).

Para elaboração desta Monografia foram utilizados três métodos principais, listados a seguir:

1. coleta de dados primários e secundários em órgãos públicos, instituições municipais e estaduais e na Internet;

2. trabalhos de campo adquirindo informações primárias diretas e verificando, validando e corrigindo as informações primárias e secundárias preexistentes;

3. síntese conclusiva realizada a partir do contraste do conhecimento obtido da aplicação dos métodos anteriores.

Estes métodos foram aplicados a partir da alocação dos seguintes recursos, todos custeados pela proponente: microcomputador, Internet, visitas aos órgãos públicos e instituições, bancos de dados, biblioteca própria, equipamentos fotográficos e GPS, etc. O equipamento GPS utilizado para obter as coordenadas dos pontos de atração ecoturísticos foi o Etrex - LEGEND, marca Garmin.

O método da coleta de dados primários e secundários em órgãos públicos, instituições municipais e estaduais e na Internet foi desenvolvido no decorrer dos meses de maio, junho, julho e agosto de 2011.

A distribuição temporal das visitas aos órgãos públicos mais importantes está registrada a seguir: - pesquisa na biblioteca pública de Agudo - 30 e 31 de maio de 2011;

- pesquisa na Secretaria Municipal da Indústria, Comércio e Turismo de Agudo - 13 a 17 de junho de 2011;

- pesquisa na biblioteca do Instituto Cultural Brasileiro de Agudo - 11 de julho de 2011;

- pesquisa na biblioteca do IBGE, em Porto Alegre - 21 de julho de 2011;

- pesquisa na biblioteca da Universidade Federal de Santa Maria - 8 de agosto de 2011;

O método da coleta de dados primários e secundários na Internet foi desenvolvido no decorrer dos meses de julho, agosto e setembro de 2011 , sendo que os principais sites utilizados estão relacionados a seguir:

www.agudo.rs.gov.br

www.camaraagudo.rs.gov.br

www.ecoviagem.com.br

www.embratur.gov.br

www.quartacolonia.com.br

www.radioagudo.com.br www.wikipedia.org

O método de trabalhos de campo, adquirindo informações primárias diretas e verificando, validando e corrigindo as informações primárias e secundárias, foi realizado durante os dias 7 de setembro a 1ำ de outubro de 2011, sendo percorridos todos os pontos de potencial ecoturísticos localizados no município, trilhas e estradas pertinentes à atividade. 
Todas as distâncias relativas aos pontos de atração ecoturística registrados neste trabalho foram obtidos a partir do marco central de entrada da Prefeitura Municipal de Agudo, coordenadas geográficas $S$

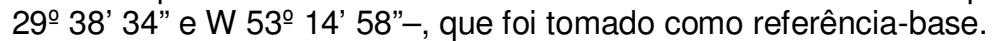

As distâncias apresentadas são as menores possíveis entre o marco central do paço da entrada da Prefeitura Municipal de Agudo, ou as de maior segurança viária, como - por exemplo - a distância relativa à Illha do Cascalho Branco, obtida transitando pela rodovia ERS 348 e dobrando à esquerda na estrada de terra que vai em direção ao Porto dos Macacos.

O trabalho de localização dos pontos de interesse ecoturístico e das distâncias entre eles e o marco central de entrada da Prefeitura Municipal de Agudo, foram controlados com comparação de imagens do site Google Earth.

Durante os trabalhos de campo foram feitos contatos com moradores dos locais ecoturísticos visitados, sendo os mais relevantes os registrados a seguir:

- Diva Müller Rohde, moradora próxima da llha do Cascalho Branco, na data de 20 de setembro de 2011 , que forneceu dados sobre o ambiente do local e sua história;

- Edinaldo Romualdo Rohde, artesão de temática naturalista e ambiental, na data de 20 de setembro de 2011;

- Osvaldo Raddatz, proprietário da Cascata Raddatz, na data de 21 de setembro de 2011, que explicou dados relativos à cascata, mudanças do curso das águas, ideias sobre a infraestrutura existente e planejada e outras cascatas adjacentes à sua propriedade;

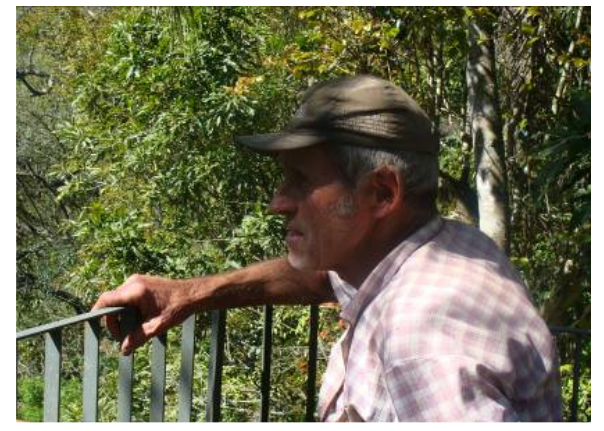

Figura 7 - Fotografia de Osvaldo Raddatz no mirante da cascata durante explicação sobre a evolução de seu empreendimento.

Fonte: Arquivo pessoal; 21 set. 2011.

- Lidiane Drews, do Balneário Drews, na data de 22 de setembro de 2011;

- Teresinha Müller Hoffmann, proprietária do Balneário Hoffmann, na data de 22 de setembro de 2011, com explicação abrangente da atual situação do ecoturismo no município;

- Itacir "Pitti" Piccinin, morador e gerenciador do Cerro Finkemberg, na data de 23 de setembro de 2011, com relato sobre o manejo silvicultural da área, das práticas de esportes radicais e de características ambientais da região;

- Lauro Reinoldo Reetz - ex-prefeito de Agudo nas gestões de 1997-2000 e 2001-2004 sobre questões referentes a ecoturismo, produtos coloniais, folclore, resgate da Casa de Cultura de Agudo e da brizoleta (atual Conselho Tutelar de Agudo) da área de inundação da Usina Hidrelétrica Dona Francisca;

- Erni Rudolfo Böck - fotógrafo profissional com amplo banco de imagens da natureza, paisagens, etc., na data de 24 de setembro de 2011, tendo explicado muitos detalhes do interior do município de Agudo, marcos geodésicos e topográficos; houve a gentil cedência de imagens para esta Monografia.

- Mariane Schiefelbein Jaeger - ex-primeira dama do município de Agudo no período de 1994 a 1996 pelas informações sobre os eventos turísticos de Agudo, na data de 28 de setembro de 2011.

O método de trabalho referente à atividade de síntese conclusiva foi realizado durante os dias 20 de setembro a 15 de outubro de 2011, sendo estabelecidas as Conclusões e Recomendações desta Monografia.

\section{REFERENCIAL TEÓRICO}


Monografias Ambientais

(e-ISSN: 2236-1308)

\subsection{Definições de ecoturismo}

A partir da consciência ambiental que surgiu em todo o globo a partir de 1992 - resultado de uma crise decorrente do moderno processo civilizatório que ameaça o futuro do planeta - , "o ecoturismo despontou como uma das respostas aos males derivados da exploração inconseqüente do turismo em massa e como uma nova forma de utilização do ambiente natural" (MACHADO, 2005, p. 13).

Os conceitos de desenvolvimento sustentável, proposta na Rio 92 - a Conferência da ONU sobre meio ambiente e desenvolvimento que reuniu representantes de 170 países -, estimularam o surgimento de uma nova modalidade turística capaz de atender às necessidades do "consumidor verde". Criaram-se, assim, produtos ecologicamente corretos, que promovem um desenvolvimento baseado na comunidade e procuram amenizar conflitos históricos no uso das áreas naturais.

A evolução mundial do ecoturismo levou a Organização Mundial do Turismo a estabelecer o ano de 2002 como o Ano Internacional do Ecoturismo, considerado retrospectivamente como o ano-base, fundador, inicial desta modalidade no mundo inteiro.

Em consonância com as megatendências mundiais, direcionar um ano ao ecoturismo foi uma forma de reconhecimento da importância econômica e social que essa atividade estava iniciando em nível mundial. Nos dias atuais, o ecoturismo é um fenômeno que já representa $10 \%$ do volume de toda atividade turística mundial, sendo um dos maiores exemplos do conceito de economia ganha-ganha.

Há muitas definições para o que seja Ecoturismo, desde a definição rasa de que constitui "a viagem responsável a áreas naturais, visando preservar o meio ambiente e promover o bem-estar da população local" (MACHADO, 2005, p. 27). O ecoturismo é mais do que isso: é, antes de mais nada, uma atividade que compreende em si um posicionamento ambiental de conservação do patrimônio natural e cultural, tanto em áreas naturais como não naturais (COSTA, 2005, p. 15), sendo que a história do ecoturismo está ligada a uma noção de turismo ao ar livre.

Algumas definições mais abrangentes de ecoturismo são apresentadas por Soifer (2005, p. 16):

- forma de desfrutar da natureza, baseado na apreciação da fauna e da flora e suas numerosas integrações entre si e com o meio ambiente (BUDOWSKI, 1990);

- turismo com a finalidade de conhecer locais ou regiões de singular qualidade natural ou ecológica, ou o fornecimento de serviços para facilitar tal turismo (ECO/92);

- um segmento da atividade turística que utiliza, de forma sustentável, o patrimônio natural e cultural, incentiva sua conservação e busca a formação de uma consciência ambientalista através da interpretação do ambiente, promovendo o bem-estar das populações envolvidas (EMBRATUR, 1993);

- constitui também uma atividade educacional que objetiva revelar significados e relações através da utilização de objetos originais, de experiência de primeira mão, e mídia ilustrativa (TILDEN, 1967).

As características gerais do ecoturismo são as seguintes (COSTA, 2005, p. 9-10):

1 - toda forma de turismo em que a motivação principal dos turistas é a observação e a apreciação da natureza, bem como as culturas tradicionais que prevalecem nas áreas naturais;

2 - contém elementos educacionais e de interpretação;

3 - em geral, mas não exclusivamente, organizado para pequenos grupos por empresas especializadas e pequenas, de propriedade local; os operadores estrangeiros de tamanhos variáveis também organizam, operam e/ou comercializam, invariavelmente para grupos reduzidos;

4 - procura reduzir ao mínimo os impactos negativos sobre o entorno natural e o sociocultural;

5 - contribui para a proteção de áreas naturais:

- gerando benefícios econômicos para as comunidades, as organizações e as autoridades locais, controlando áreas naturais com finalidades de conservação;

- fornecendo oportunidades alternativas de emprego e de renda para comunidades locais;

- incrementando a conscientização para a conservação de recursos naturais e culturais entre habitantes locais e turistas.

Para a EMBRATUR, em 1994 (COSTA, 2005, p.40), a atividade ecoturística deve abranger como características conceituais:

- a dimensão do conhecimento da natureza;

- a experiência educacional interpretativa; 
Monografias Ambientais

- a valorização das culturas tradicionais locais, e

- a promoção do desenvolvimento sustentável.

Entre os princípios de ecoturismo utilizados pelos empreendedores no Brasil pode-se registrar (SOIFER, 2005, p. 16):

- tem um foco primário em visitar ambientes naturais relativamente remotos e inalterados;

- mantém um baixo impacto sobre o ambiente natural, sem alterar o recurso;

- há ênfase educacional e desejo de aprender sobre a história natural e cultural dos lugares visitados;

- há benefícios diretos à economia e aos habitantes locais; colabora com a preservação de áreas naturais;

- promove o crescimento econômico enquanto protege o ambiente natural;

- a agência ajuda a custear o controle de suas atividades, contribuindo com a preservação ambiental;

- os viajantes devem ter o espírito da apreciação, participação e sensibilidade.

Os princípios de ecoturismo sustentável podem ser identificados conforme a seguir (SWARBROOKE, 2000, p. 65- 66 e 67):

- não deve degradar os recursos e deve ser desenvolvido de maneira completamente ambiental;

- deve possibilitar experiências participativas e esclarecedoras em primeira mão;

- deve envolver educação entre todas as partes - comunidades locais, governo, organizações nãogovernamentais, indústria e turistas (antes, durante e depois da viagem);

- incentivar em todos os envolvidos e valorizar o intrínseco dos recursos naturais e culturais;

- deve implicar aceitação dos recursos tais como são e reconhecer os seus limites, o que pressupõe uma administração voltada para o abastecimento;

- promover a compreensão e as parcerias entre os envolvidos, incluindo o governo, ONGs, a indústria, os cientistas e a população local (tanto antes como durante as operações);

- deve promover responsabilidade e um comportamento moral e ético em relação ao meio ambiente natural e cultural, por parte de todos os envolvidos;

- trazer benefícios em longo prazo - para os recursos naturais e culturais, a comunidade e a indústria local (esses benefícios podem ser de preservação científica, social, cultural ou econômica);

- assegurar que as operações de ecoturismo a ética inerente a práticas ambientais responsáveis se aplique aos recursos externos (naturais e culturais) que atraem turistas, e as suas operações internas.

O ecoturismo abrange muitas formas e modalidades, todas elas ligadas a natureza, meio ambiente, locais abertos e rurais. De forma bem abrangente, pode-se delimitar algumas destas modalidades como descrito abaixo (MACHADO, 2005):

- turismo de natureza - a prática da atividade turística que decorre da visitação pura e simples do espaço natural; nessa modalidade, não há comprometimento maior por parte do agente ou do turista, apenas o desejo de contato direto com o ambiente e um cuidado relativo na manutenção do espaço utilizado; representa um grande potencial já utilizado em diversos locais e leva cada vez mais grupos a descobrirem, no contato com a natureza, um modo interessante de fazer turismo, aproveitando as belezas e os caminhos encontrados no interior dos municípios (MACHADO, 2005, p. 29);

- turismo ecocientífico - contato com o ambiente natural cujo objetivo seja o conhecimento aprofundado do meio é chamado Turismo Ecocientífico. Há, neste caso, uma valorização principalmente da biodiversidade ou de espécies determinadas, a fim de conhecimento e/ou estudo, bem como interesse direcionado aos costumes locais (MACHADO, 2005, p. 30-31);

- turismo ambiental - prática turística ligada aos conceitos amplos de conhecimento e interação com o ambiente natural, através de atividades específicas de conhecimento e comparação, resultado da compreensão das ações do homem no ambiente natural (MACHADO, 2005, p. 32);

- turismo de aventura - segmento do turismo que proporciona atividades ligadas à natureza, buscando a superação de limites pessoais com segurança e responsabilidade na utilização do meio ambiente (MACHADO, 2005, p. 33); suas atividades englobam modalidades de água: como rafting, canoagem e 
hidrospeed; ar: como paraglider, paraquedismo e balonismo e terra: como rapel, cascade e caminhadas; segmento do mercado turístico que promove a prática de atividades de aventura e esporte recreacional, em ambientes naturais e espaços urbanos ao ar livre, que envolvam emoções e riscos controlados, exigindo o uso de técnicas e equipamentos específicos, a adoção de procedimentos para garantir a segurança pessoal e de terceiros e o respeito ao patrimônio ambiental e sociocultural (COSTA, 2005, p. 44-45);

- turismo rural - segmento da atividade turística que se desenvolve em propriedades produtivas, aliando práticas de agropecuária e valorizando o contato direto do turista com a cultura do local (MACHADO, 2005, p. 35).

A comparação contrastiva (= "diferenças") leva a uma compreensão mais didática entre estas diversas formas de ecoturismo (MACHADO, 2005).

Quadro 1 - Diferença entre o Ecoturismo e o Turismo de Natureza.

Fonte: MACHADO, 2005, p. 30.

\begin{tabular}{|c|c|c|}
\hline & ECOTURISMO & TURISMO DE NATUREZA \\
\hline Palavra chave & Conservação & Lazer ao ar livre \\
\hline Ocorrência & Áreas naturais preservadas & Áreas naturais \\
\hline Operação & $\begin{array}{l}\text { Relação com a manutenção do } \\
\text { ambiente }\end{array}$ & $\begin{array}{l}\text { Despreocupação quanto a processos } \\
\text { mais diretos de manutenção do } \\
\text { ambiente }\end{array}$ \\
\hline Cuidados & Extremos & Simples \\
\hline Conhecimento do local & Profundo & Superficial \\
\hline Objetivos & $\begin{array}{l}\text { Conhecimento amplo do ambiente } \\
\text { natural e cultural }\end{array}$ & $\begin{array}{l}\text { Relaxamento e prazer no ambiente } \\
\text { natural }\end{array}$ \\
\hline Grupos & Reduzidos & Médios e grandes \\
\hline Envolvimento local & Sempre & Não necessariamente \\
\hline Agentes de turismo & $\begin{array}{l}\text { Envolvimento direto com os projetos } \\
\text { ambientais }\end{array}$ & $\begin{array}{l}\text { Sem envolvimento com os projetos } \\
\text { ambientais }\end{array}$ \\
\hline Envolvimento cultural & Diretamente identificado & Sem projetos culturais obrigatórios \\
\hline Público & $\begin{array}{llll}\text { Preocupado com } & \text { as } & \text { questões } \\
\text { ambientais }\end{array}$ & Desejoso de contato com a natureza \\
\hline Programas & $\begin{array}{l}\text { Dentro dos conceitos de mínimo } \\
\text { impacto }\end{array}$ & $\begin{array}{l}\text { Possíveis de } \\
\text { natural }\end{array}$ \\
\hline
\end{tabular}

Quadro 2 - Diferença entre o Ecoturismo e o Turismo Ecocientífico.

Fonte: MACHADO, 2005, p. 31. 
Monografias Ambientais

(e-ISSN: 2236-1308)

\begin{tabular}{|c|c|c|}
\hline & ECOTURISMO & TURISMO ECOCIENTIFICO \\
\hline Palavra chave & Conservação & Pesquisa \\
\hline Ocorrência & Áreas naturais preservadas & Áreas naturais preservadas \\
\hline Operação & $\begin{array}{lll}\text { Diretamente } & \text { relacionada } & \text { com } \\
\text { manutenção do ambiente } & \end{array}$ & $\begin{array}{llll}\text { Diretamente relacionada } & \text { com } & \text { a } \\
\text { atividade científica } & & \end{array}$ \\
\hline Cuidados & Extremos & Extremos \\
\hline Conhecimento do local & Profundo & Científico \\
\hline Objetivos & $\begin{array}{l}\text { Conhecimento amplo do ambiente } \\
\text { natural e cultural }\end{array}$ & Conhecimento técnico do ambiente \\
\hline Grupos & Reduzidos & Muito reduzidos \\
\hline Envolvimento local & Sempre & Não necessariamente \\
\hline Agentes de turismo & $\begin{array}{l}\text { Envolvimento direto com os projetos } \\
\text { ambientais }\end{array}$ & Nem sempre necessários \\
\hline Envolvimento cultural & Diretamente identificado & Nem sempre necessários \\
\hline Público & $\begin{array}{l}\text { Preocupado com as questões } \\
\text { ambientais }\end{array}$ & Técnicos, professores, estudiosos \\
\hline Programas & $\begin{array}{l}\text { Dentro dos conceitos de mínimo } \\
\text { impacto }\end{array}$ & Quando ocorrem, apenas relaxamento \\
\hline
\end{tabular}

Quadro 3 - Diferença entre o Ecoturismo e o Turismo Ambiental.

Fonte: MACHADO, 2005, p. 33.

\begin{tabular}{|c|c|c|}
\hline & ECOTURISMO & TURISMO AMBIENTAL \\
\hline Palavra chave & Conservação & Educação ambiental \\
\hline Ocorrência & Áreas naturais preservadas & $\begin{array}{lll}\text { Áreas naturais } & \text { preservadas } & \text { ou } \\
\text { degradadas } & & \end{array}$ \\
\hline Operação & $\begin{array}{lll}\text { Diretamente } & \text { relacionada } & \text { com } \\
\text { manutenção do ambiente } & \end{array}$ & $\begin{array}{llll}\text { Diretamente relacionada } & \text { com } & \text { a } \\
\text { atividade educativa } & & \end{array}$ \\
\hline Cuidados & Extremos & Extremos \\
\hline Conhecimento do local & Profundo & Profundo \\
\hline Objetivos & $\begin{array}{l}\text { Conhecimento amplo do ambiente } \\
\text { natural e cultural }\end{array}$ & $\begin{array}{l}\text { Conhecimento do ambiente e das } \\
\text { modificações nele ocorridas }\end{array}$ \\
\hline Grupos & Reduzidos & Médios e grandes \\
\hline Envolvimento local & Sempre & Não necessariamente \\
\hline
\end{tabular}


Monografias Ambientais

(e-ISSN: 2236-1308)

\section{REMOANFSM}

\begin{tabular}{|l|l|l|}
\hline Agentes de turismo & $\begin{array}{l}\text { Envolvimento direto com os projetos } \\
\text { ambientais }\end{array}$ & Envolvimento com educação ambiental \\
\hline Envolvimento cultural & Diretamente identificado & Não necessariamente \\
\hline Público & $\begin{array}{l}\text { Preocupado com as questões } \\
\text { ambientais }\end{array}$ & $\begin{array}{l}\text { Professores, estudiosos, alunos e } \\
\text { interessados }\end{array}$ \\
\hline Programas & $\begin{array}{l}\text { Dentro dos conceitos de mínimo } \\
\text { impacto }\end{array}$ & $\begin{array}{l}\text { Relacionando ações e consequências } \\
\text { no ambiente }\end{array}$ \\
\hline
\end{tabular}


Monografias Ambientais

(e-ISSN: 2236-1308)

REMOANFSM

Quadro 4 - Diferença entre o Ecoturismo e o Turismo de Aventura.

Fonte: MACHADO, 2005, p. 35.

\begin{tabular}{|c|c|c|}
\hline & ECOTURISMO & TURISMO DE AVENTURA \\
\hline Palavra chave & Conservação & Risco controlado \\
\hline Ocorrência & Áreas naturais preservadas & Áreas naturais \\
\hline Operação & $\begin{array}{lll}\text { Diretamente } & \text { relacionada } & \text { com } \\
\text { manutenção do ambiente } & \end{array}$ & $\begin{array}{l}\text { Relacionada a atividades esportivas de } \\
\text { natureza }\end{array}$ \\
\hline Cuidados & Extremos & Básicos \\
\hline Conhecimento do local & Profundo & $\begin{array}{l}\text { Apenas para a prática da modalidade } \\
\text { esportiva }\end{array}$ \\
\hline Objetivos & $\begin{array}{l}\text { Conhecimento amplo do ambiente } \\
\text { natural e cultural }\end{array}$ & Atividade física na natureza \\
\hline Grupos & Reduzidos & Reduzidos \\
\hline Envolvimento local & Sempre & $\begin{array}{l}\text { Ocorre quando necessário para } \\
\text { suporte da atividade }\end{array}$ \\
\hline Agentes de turismo & $\begin{array}{l}\text { Envolvimento direto com os projetos } \\
\text { ambientais }\end{array}$ & Capacitados para a modalidade \\
\hline Envolvimento cultural & Diretamente identificado & Geralmente não ocorre \\
\hline Público & $\begin{array}{llll}\text { Preocupado } & \text { com } & \text { as } & \text { questões } \\
\text { ambientais }\end{array}$ & $\begin{array}{l}\text { Ávido por atividades físicas no meio } \\
\text { natural }\end{array}$ \\
\hline Programas & $\begin{array}{l}\text { Dentro dos conceitos de mínimo } \\
\text { impacto }\end{array}$ & $\begin{array}{l}\text { Sempre ligados a práticas esportivas } \\
\text { de risco controlado }\end{array}$ \\
\hline
\end{tabular}

Quadro 5 - Diferença entre o Ecoturismo e o Turismo Rural.

Fonte: MACHADO, 2005, p. 37.

\begin{tabular}{|l|l|l|}
\hline & ECOTURISMO & TURISMO RURAL \\
\hline Palavra chave & Conservação & Atividade agropecuária \\
\hline Ocorrência & Áreas naturais preservadas & Área rural \\
\hline Operação & $\begin{array}{l}\text { Diretamente relacionada com } \\
\text { manutenção do ambiente }\end{array}$ & $\begin{array}{l}\text { Relacionada às atividades turísticas no } \\
\text { meio rural onde há atividade } \\
\text { agropecuária }\end{array}$ \\
\hline
\end{tabular}


Monografias Ambientais

(e-ISSN: 2236-1308)

REMOANFSM

\begin{tabular}{|c|c|c|}
\hline Cuidados & Extremos & Básicos \\
\hline Conhecimento do local & Profundo & Superficial \\
\hline Objetivos & $\begin{array}{l}\text { Conhecimento amplo do ambiente } \\
\text { natural e cultural }\end{array}$ & Lazer no meio rural \\
\hline Grupos & Reduzidos & Reduzidos a médios \\
\hline Envolvimento local & Sempre & $\begin{array}{l}\text { Ocorre diretamente } \\
\text { proprietários }\end{array}$ \\
\hline Agentes de turismo & $\begin{array}{l}\text { Envolvimento direto com os projetos } \\
\text { ambientais }\end{array}$ & $\begin{array}{l}\text { A atividade é geralmente exercida } \\
\text { pelos próprios proprietários }\end{array}$ \\
\hline Envolvimento cultural & Diretamente identificado & Diretamente identificado \\
\hline Público & $\begin{array}{l}\text { Preocupado com } \\
\text { ambientais }\end{array}$ & $\begin{array}{l}\text { Ávido por atividades de lazer no meio } \\
\text { rural e recepção mais pessoal }\end{array}$ \\
\hline Programas & $\begin{array}{l}\text { Dentro dos conceitos de mínimo } \\
\text { impacto }\end{array}$ & Sempre ligados às práticas campeiras \\
\hline
\end{tabular}

O futuro do ecoturismo está em constante modificação, pois, a cada dia, novas posturas decorrentes da responsabilidade assumida pelas gerações em seu relacionamento com a natureza dão origem a formas diferenciadas de apropriação e manejo das paisagens, dos recursos naturais, dos acidentes geográficos e do planeta como um todo.

A agressão sofrida pela natureza em todas as partes da Terra, proveniente de um processo de ocupação e utilização constante e sempre progressivo dos recursos naturais, leva a uma postura diferente e, consequentemente, a uma nova forma de atuação quanto à paisagem e novas formas pedagógicas de educação.

Nessa nova ação dos seres humanos em seu contato com o ambiente natural e na exploração dos recursos disponibilizados pelo ecoturismo é que se concentra a nova perspectiva de atuação da educação ambiental: ultrapassando valores antigos egoístas, egocêntricos e exploradores, surgem uma ética solidária, comprometida e cuidadosa, corretamente adaptada á visão da sustentabilidade:

"Esta é a proposta do ecoturismo. Uma atividade solidária, voltada para o desenvolvimento integral, que mantém os valores naturais do ambiente em que é executada e respeita as características culturais das populações, verdadeiras expressões das atividades humanas integradas num determinado tempo e espaço" (MACHADO, 2005, p. 224).

\subsection{Modalidades de ecoturismo existentes ou potencialmente possíveis em Agudo}

Dentre as diversas modalidades de ecoturismo existentes atualmente no município de Agudo ou que sejam potencialmente possíveis, cabe destacar as seguintes:

\section{NA TERRA}

- caminhada

- caminhada em trilhas

- caminhada em picadas

- cavalgada

- ciclismo

- cicloturismo (mountain biking)

- escalada

- escurcionismo

- espeleologia 


\section{Monografias Ambientais}

- excursões científicas de geologia, botânica, paleontologia, biologia, etc.

- fora-de-estrada (off-road)

- hikking

- motociclismo

- MotoCross

- observação de aves

- orientação - caminhada, corrida

- trekking

NO AR

- balonismo

- paraglider (ou parapente)

- paraquedismo

- vôo livre (asa-delta)

NA ÁGUA

- caiaque

- canoagem

- natação e mergulho

- navegação fluvial

- observação de cascatas e quedas d'água

- pesca

MODALIDADES MISTAS

- arvorismo ou arborismo

- caça regulamentada

- cascade

- estudos do meio ambiente

- rapel

\section{POTENCIAL ECOTURÍSTICO}

Os principais pontos ecoturísticos existentes, e registrados no "Mapa Ecoturístico do Município de Agudo", estão descritos a seguir, constituindo um patrimônio das gerações presentes e futuras que deve ser valorizado e preservado através da conscientização dos próprios habitantes do município bem como dos visitantes e turistas que buscam o contato com o ambiente natural e sua biodiversidade.

\section{MORRO AGUDO}

Símbolo no Mapa: MA

Distância da sede: $2 \mathrm{~km}$

Coordenadas geográficas: S 29 $38^{\prime} 40^{\prime \prime}$ W 53ำ 17' 28"

Altitude: 447 metros

Projeto Geoparque da Quarta Colônia: enquadrado como geomonumento.

O nome do município surgiu em virtude deste morro - Morro Agudo - pelos primeiros colonizadores alemães em função de sua forma pontiaguda. Fica localizado a 2 quilômetros à oeste da cidade, com 429 metros de altura (Figura 8).

A trilha do Morro Agudo é caracterizada pela diversidade ambiental e pela paisagem rural composta por agricultores que estão trabalhando nas suas lavouras, campos, matas secundárias, formações de rochas entre outras belezas naturais e representações da cultura local. A vegetação que prevalece no morro é típica de áreas pedregosas e áridas, com cactos e bromélias em seu ponto mais alto. Do alto do morro se pode visualizar quatro municípios da região: Agudo, Dona Francisca, São João do Polêsine, Restinga Seca, as várzeas do Rio Jacuí que serpenteia por toda a região.

Em volta da base do morro são cultivados fumo, milho, mandioca e feijão. Existe a presença de capoeirões e pastagens. 


\section{Monografias Ambientais}

A mata que envolve o morro é composta por espécies nativas tais como cedro, angico, grápia, ipê, louro, cabriúva, pessegueiro-bravo, timbaúva, taquaruçu, entre outras. Sobre as árvores e as rochas existem espécies de orquídeas-do-mato, barba-de-pau, cactos, samambaias, flores, etc.

O topo do morro (Figura 10) é formado por um agrupamento de rochas basálticas destacando-se três grandes blocos; a rocha que fica no ponto culminante tem uma área aproximada de dois metros quadrados, rodeada por outras:

Lá, as árvores são de porte pequeno e retorcidas, dando-nos a impressão de um cerrado, isto em conseqüência da diminuição da temperatura devido a sua altitude e também em virtude do solo escasso, pois elas crescem entre as rochas (HOPPE, 1992, p. 85-86).

O acesso aos rochedos é difícil e perigoso, havendo somente uma largura aproximada de 2 metros e abismos à volta. A fauna no morro apresenta várias espécies, desde aves como o tucano, até bugios, cobras e lagartos.

Uma bela descrição de "Uma Caminhada ao Morro" é apresentada em livro didático (HOPPE, 1992, p. 85-86), "um cenário da natureza que causa curiosidade e admiração".

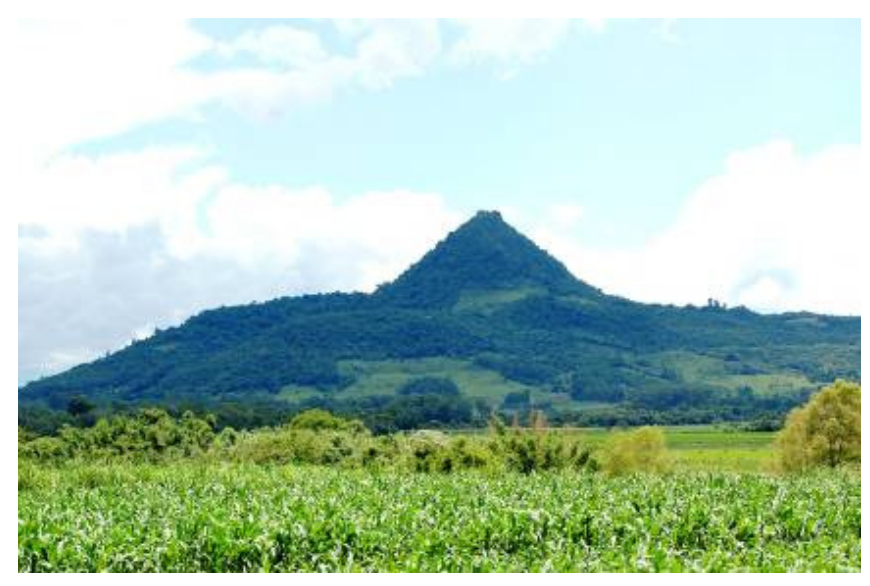

Figura 8 - Fotografia do Morro Agudo.

Fonte: Acervo de Erni Bock; 25 jan. 2006.

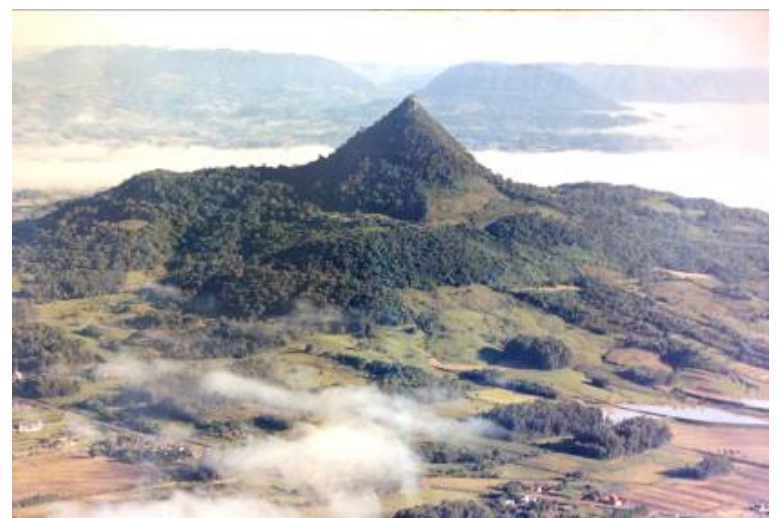

Figura 9 - Fotografia aérea do Morro Agudo. Fonte: Acervo de Erni Bock; 1ํago. 2008. 
Monografias Ambientais

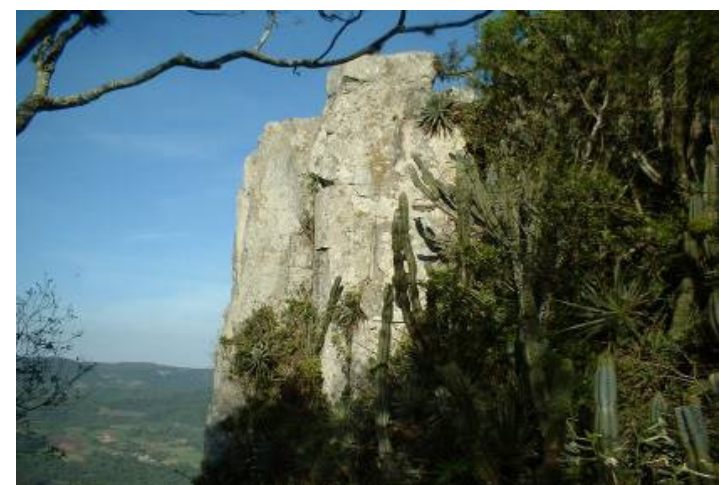

Figura 10 - Fotografia do topo do Morro Agudo. Fonte: Acervo de Cláudia Bernardini; 23 jan. 2006.

\section{CERRO FINKEMBERG}

Símbolo no Mapa: CF

Distância da sede: $4,8 \mathrm{~km}$

Coordenadas geográficas: S 29 $36^{\prime}$ 58" W 53ำ 14' 57"

Altitude: $521 \mathrm{~m}$

O Cerro Finkemberg se localiza ao norte da área urbana de Agudo, sendo alcançado pela Linha Branca, a 5 quilômetros da sede. Possui rampa de asa delta e parapente, mantida pelo proprietário, senhor Itacir "Pitti" Piccinin, em uma área de 8 hectares. Mesmo realizando intenso e bem estruturado paisagismo no topo do Cerro e arredores, o proprietário permite a livre entrada de visitantes, turistas e desportistas em geral.

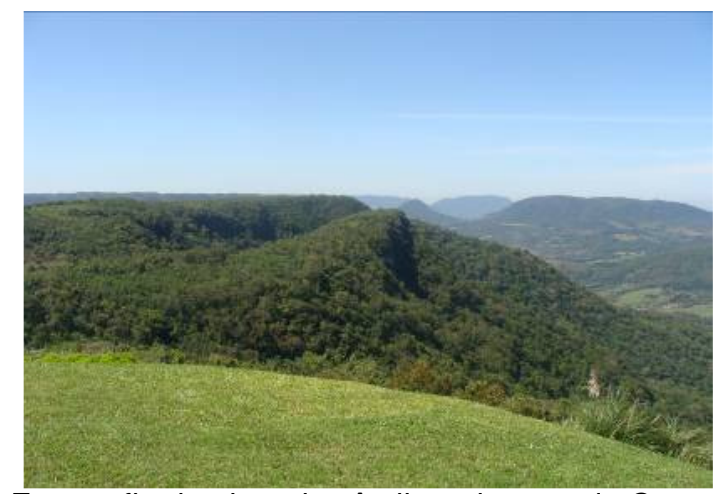

Figura 11 - Fotografia da pista de vôo livre do topo do Cerro Finkemberg. Fonte: Arquivo pessoal; 22 set. 2011. 
Monografias Ambientais

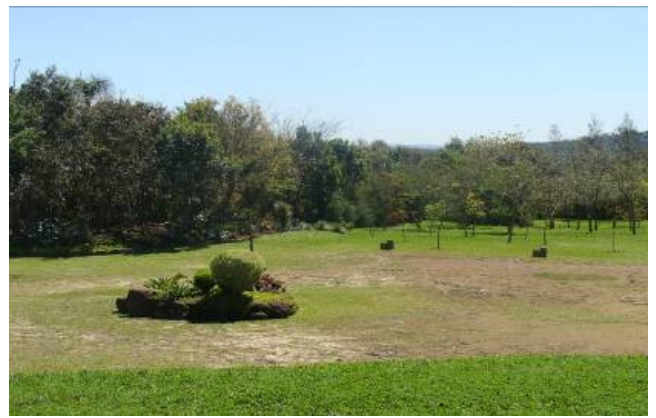

Figura 12 - Fotografia do paisagismo no topo do Cerro Finkemberg. Fonte: Arquivo pessoal; 22 set. 2011.

\section{CASCATA RADDATZ}

Símbolo no Mapa: CR

Distância da sede: $11,5 \mathrm{~km}$

Coordenadas geográficas: S 29 35' 11" W 53ำ 10' 46"

Altitude: $270 \mathrm{~m}$

A cascata Raddatz é uma queda d'água com 18 metros de altura (conforme depoimento pessoal do senhor Osvaldo Raddatz, no dia 21 de setembro de 2011), localizada na localidade de Linha Nova, a 11,5 quilômetros da sede; constitui propriedade particular da família Raddatz, sendo um dos pontos ecoturísticos mais visitados de Agudo. O local possui infraestrutura bem adequada de lazer.

Em meio à natureza exuberante, cercada de Mata Atlântica com uma rica flora de plantas, como bromélias e orquídeas, fontes de águas límpidas, encontra-se a cascata em cavidade geológica de 32 metros de profundidade, atingível por escada bem segura com corrimão e com 132 degraus. Há um mirante no topo do conjunto que permite a sua visão integral.

No trajeto do centro urbano de Agudo até a cascata Raddatz, em caminhos de estrada de chão passa-se por locais interessantes, como a Linha Branca, paredões de rochas basálticas, propriedades de pequenos agricultores e algumas casas típicas da época da colonização alemã, feitas em estrutura de enxaimel.

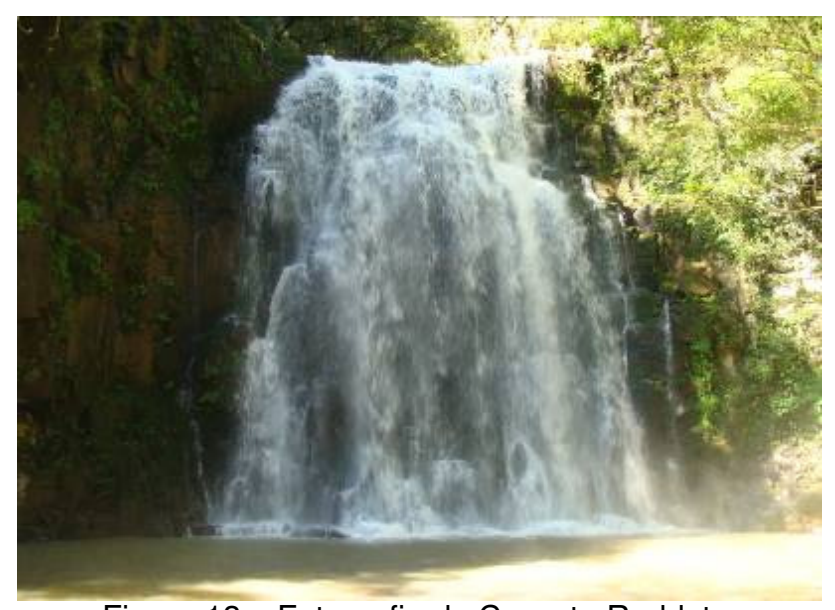

Figura 13 - Fotografia da Cascata Raddatz.

Fonte: Arquivo pessoal; 21 set. 2011. 
Monografias Ambientais

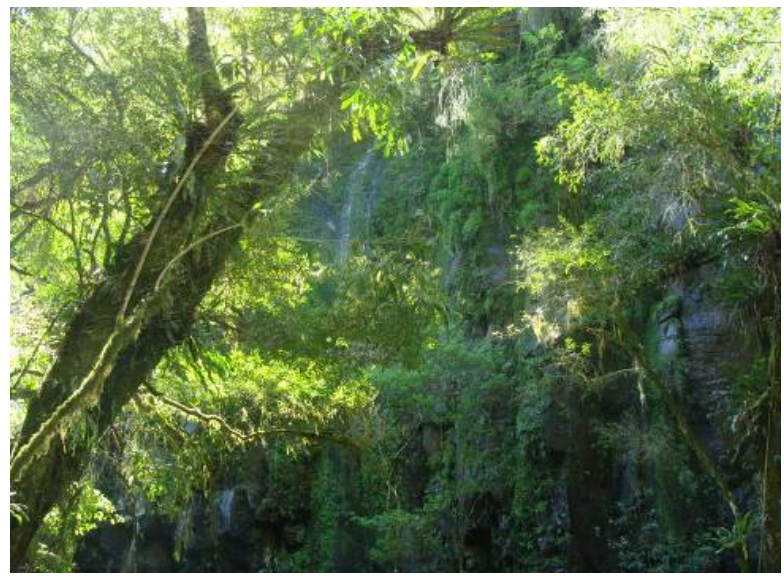

Figura 14 - Fotografia de detalhe da natureza na Cascata Raddatz. Fonte: Arquivo pessoal; 21 set. 2011.

\section{PONTO CULMINANTE DE AGUDO}

Símbolo no Mapa: PCA

Distância da sede: $24,5 \mathrm{~km}$

Coordenadas geográficas: S 29 33' 02" W 53ํ0' 08"

Altitude: $590 \mathrm{~m}$ (587 m pelo GPS)

O Ponto Culminante de Agudo fica localizado na estrada que vai até a Gruta do Índio, a 24,5 quilômetros da sede.

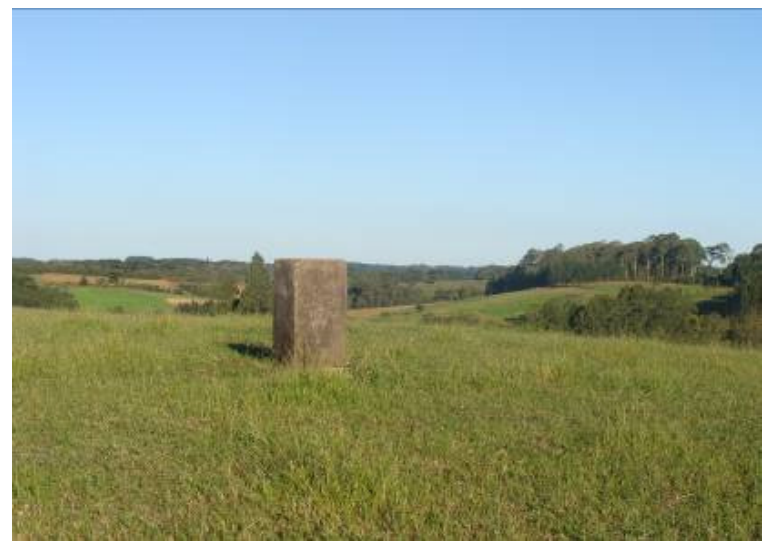

Figura 15 - Fotografia do marco no local do Ponto Culminante de Agudo.

Fonte: Arquivo pessoal; 21 set. 2011.

\section{GRUTA DO ÍNDIO}

\section{Símbolo no Mapa: GI}

Distância da sede: $27,1 \mathrm{~km}$

Coordenadas geográficas: S 2932' 20" W 53ํ06' 50" (entrada maior)

Altitude: $418 \mathrm{~m}$

Projeto Geoparque da Quarta Colônia: enquadrado como geomonumento.

A Gruta do Índio está localizada a 27 quilômetros da sede, no norte do município, na localidade de Linha dos Pomeranos. 


\section{Monografias Ambientais}

Constitui-se em gruta-caverna de arenito, com uma entrada maior de aproximadamente 15 metros de largura por 8 metros de altura e outra, menor (considerada atualmente como "saída"). Há um ramo da caverna que não tem saída, possuindo aproximadamente 80 metros de tamanho.

No local, segundo a tradição da comunidade antiga, habitaram povos indígenas. As características da gruta em arenito e seu mistério fazem com que ela se transforme em um ponto de interesse para visitação. É mal sinalizada, sendo recoberta pela vegetação alta e dentro dela é necessário levar equipamentos de iluminação, pois não há luz natural suficiente para encaminhamento em seu interior.

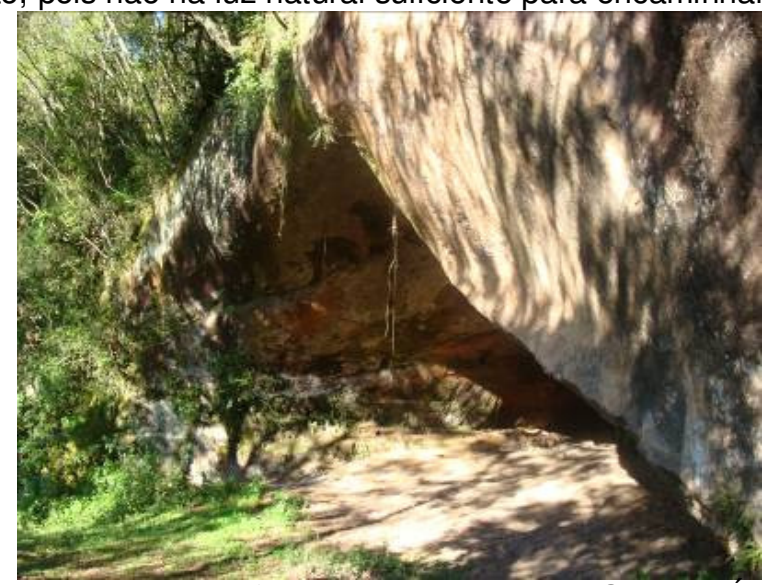

Figura 16 - Fotografia da entrada maior da Gruta do Indio. Fonte: Arquivo pessoal; 21 set. 2011.

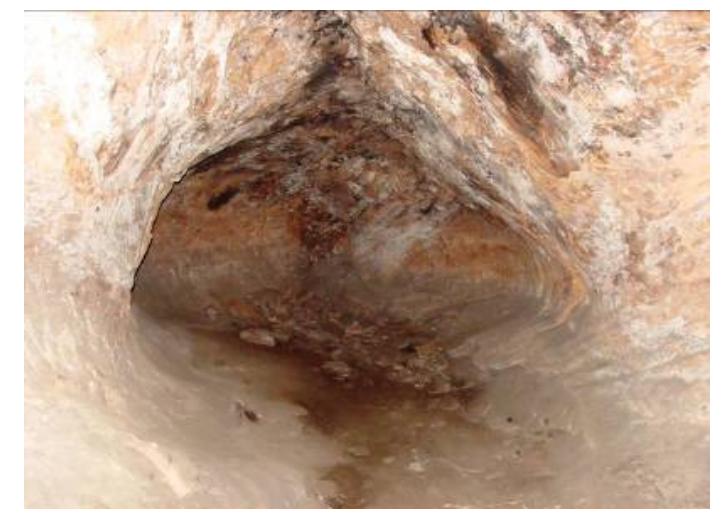

Figura 17 - Fotografia do fundo da caverna da Gruta do Índio. Fonte: Arquivo pessoal; 21 set. 2011. 


\section{Monografias Ambientais}

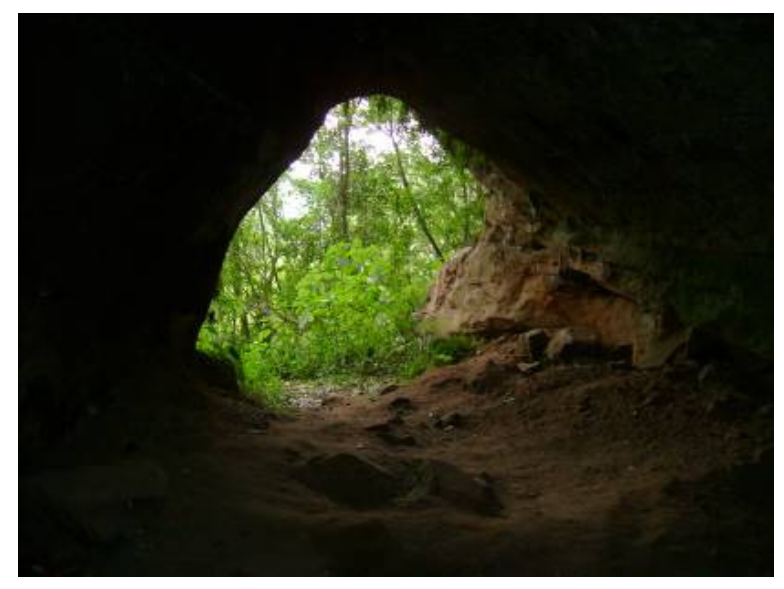

Figura 18 - Fotografia da entrada menor ("saída") da caverna da Gruta do Índio. Fonte: Arquivo pessoal; 21 set. 2011.

\section{CASCATA DO CHUVISCO}

\section{Símbolo no Mapa: CC}

Distância da sede: $23,8 \mathrm{~km}$ (início da trilha de $800 \mathrm{~m}$ )

Coordenadas geográficas do início da trilha: S 29 $33^{\prime} 41^{\prime \prime}$ W 53을 $09^{\prime} 12^{\prime \prime}$

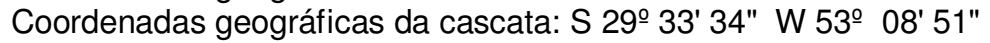

Altitude: $483 \mathrm{~m}$

A Cascata do Chuvisca fica localizada na localidade de Linha dos Pomeranos, tendo 46 metros de queda da água

Para se chegar até a cascata é necessário percorrer uma trilha de dificuldade média de 800 metros em meio à Mata Atlântica na qual há um contato intenso com a fauna e flora, além de processos de formação da paisagem.

Em função da precariedade das estradas de acesso, da má sinalização e da relativa dificuldade apresentada pela trilha, é um dos locais ecoturísticos menos conhecido de Agudo.

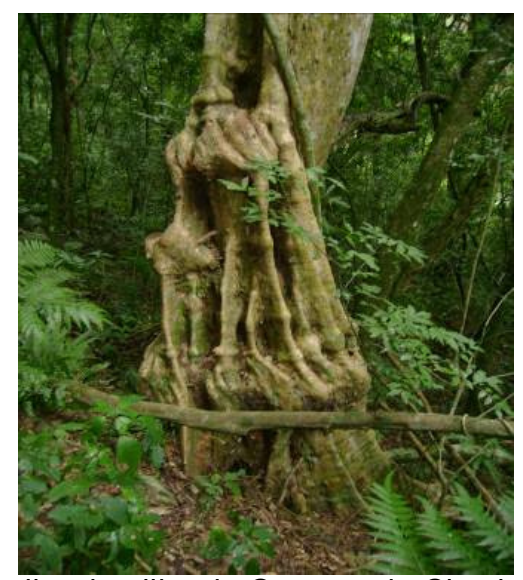

Figura 19 - Fotografia de detalhe da trilha da Cascata do Chuvisco, interior da Mata Atlântica.

Fonte: Acervo de Geraldo Mario Rohde; 28 jun. 2006. 


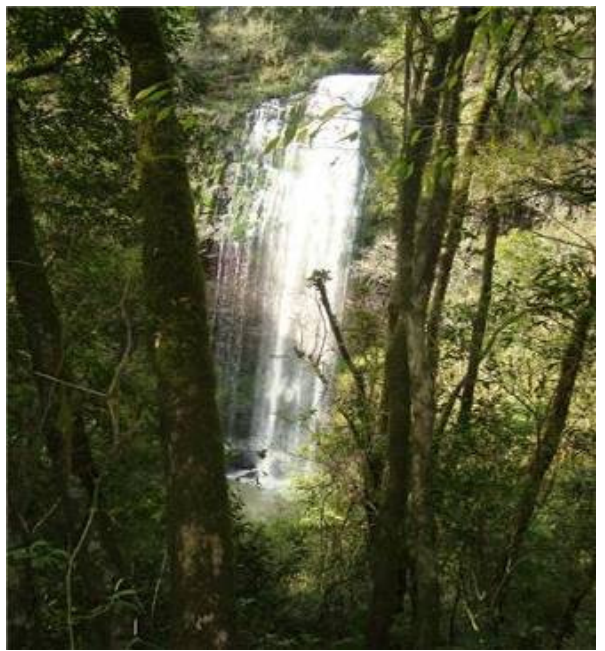

Figura 20 - Fotografia da Cascata do Chuvisco.

Fonte: Acervo de Cláudia Bernardini; 27 set. 2009.

\section{ILHA DO CASCALHO BRANCO}

\section{Símbolo no Mapa: ICB}

Distância da sede: 15,0 km

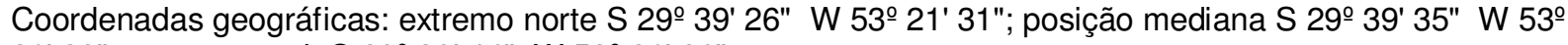

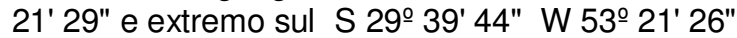

Altitude: $40 \mathrm{~m}$

A llha do Cascalho Branco fica situada no rio Jacuí, a cerca de 15 quilômetros da sede do município de Agudo; para chegar até ela é necessário trafegar pela ERS 348, dobrando à esquerda na entrada em direção ao Porto dos Macacos.

Nas adjacências da estrada de chão que leva até a ilha há plantações de milho, mandioca, hortaliças e frutas, predominando a paisagem das plantações de arroz. No lado do município de Agudo, está localizada a praia de Campo Bonito (coordenadas S 29ํ39' 15" e W 53ํ21' 25"; alt. 40 m). Este local é utilizado como área de lazer e camping.

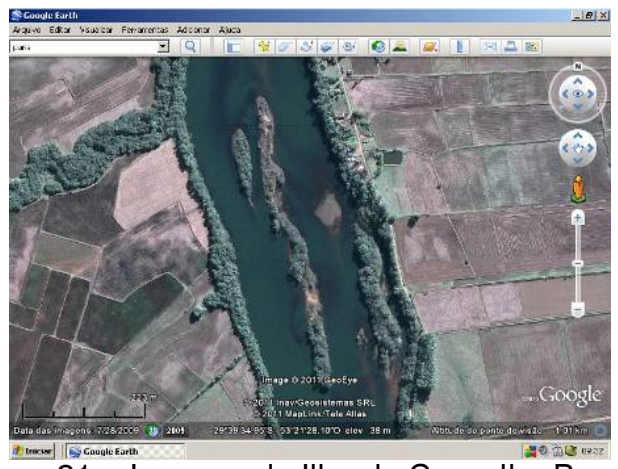

Figura 21 - Imagem da llha do Cascalho Branco. Fonte: Google Earth. 
Monografias Ambientais

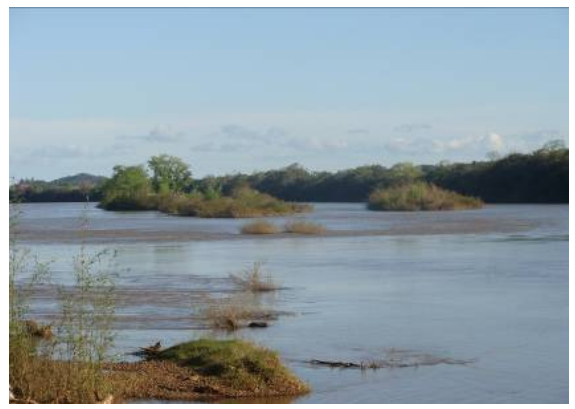

Figura 22 - Fotografia da llha do Cascalho Branco.

Fonte: Arquivo pessoal; 20 set. 2011.

\section{BALNEÁRIO DREWS}

Símbolo no Mapa: BD

Distância da sede: 15,7 km

Coordenadas geográficas: S 29 33' 15" W 53ํ 15' 48"

Altitude: $76 \mathrm{~m}$

O Balneário Drews fica localizado na Linha Boêmia, nas margens do arroio Corupá, a 15,7 quilômetros da sede, disponibiliza infraestrutura de camping e motor home, trilhas para caminhadas, piscinas com água tratada, bar, lancheria, área verde com muita sombra, área de pesca, campo de futebol e vôlei na areia, cancha de bocha e pracinha, cabanas para hospedagem, churrasqueiras, venda de produtos coloniais além de uma gruta com a imagem do Santo Expedito; fica aberto de dezembro a março.

Neste balneário ocorrem eventos programados anualmente, devido à infraestrutura que disponibiliza. Dentre eles, o concurso local do Garota-Verão.

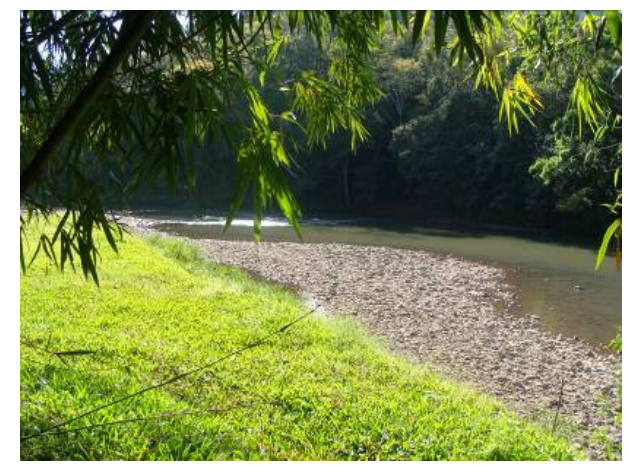

Figura 23 - Fotografia do Balneário Drews.

Fonte: Arquivo pessoal; 22 set. 2011.

\section{BALNEÁRIO HOFFMANN}

\section{Símbolo no Mapa: BH}

Distância da sede: $18,8 \mathrm{~km}$

Coordenadas geográficas: S 29 32' 56" W 53ำ 13' 51"

Altitude: $90 \mathrm{~m}$

O Balneário Hoffmann está localizado na Linha Boêmia, nas margens do arroio Corupá, a 18,8 quilômetros da sede, junto ao arroio Corupá, em mata nativa com muita sombra; no arroio um há poço com 3 metros de profundidade que é uma excelente opção para banho. Uma ponte pênsil rústica, para 


\section{Monografias Ambientais}

pedestres, que representa uma verdadeira aventura atravessá-la, localiza-se na Linha Boêmia a 18,8 quilômetros da sede.

Disponibiliza infraestrutura básica de camping, trilhas para caminhadas, bar, lancheria, área verde com muita sombra, área de pesca, campo de futebol e vôlei; cancha de bocha e pracinha infantil, venda de produtos coloniais; fica aberto de dezembro a março.

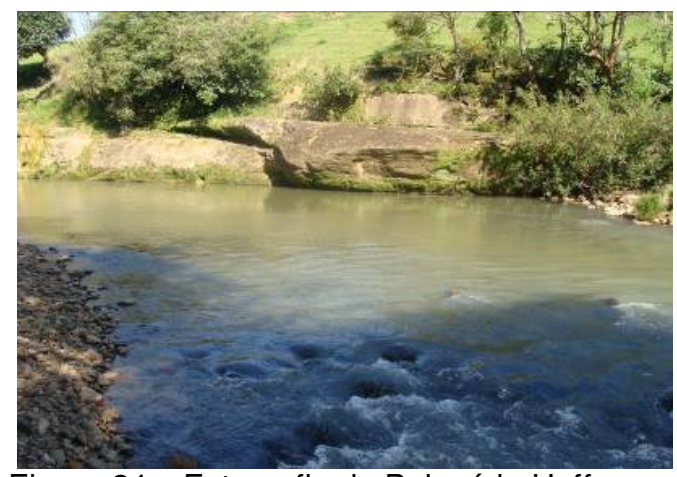

Figura 24 - Fotografia do Balneário Hoffmann.

Fonte: Arquivo pessoal; 22 set. 2011.

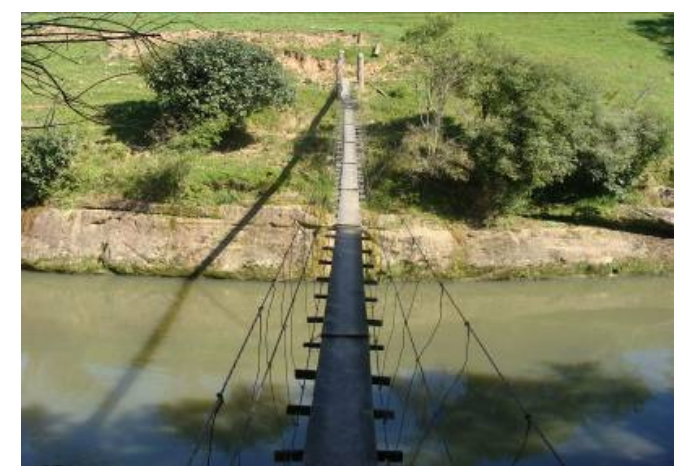

Figura 25 - Fotografia de detalhe do Balneário Hoffmann.

Fonte: Arquivo pessoal; 22 set. 2011.

\section{CERRO DA IGREJA}

Símbolo no Mapa: Cl

Distância da sede: $18,0 \mathrm{~km}$

Coordenadas geográficas: S 29 32' 11" W 53ำ17' 22"

Altitude: $519 \mathrm{~m}$

Projeto Geoparque da Quarta Colônia: enquadrado como geomonumento.

O Cerro da Igreja está localizado a 18 quilômetros da sede, na estrada de Picada do Rio em direção a Usina Hidrelétrica Dona Francisca, na localidade de Nova Boêmia. Rio Jacuí.

Do seu ponto mais elevado é possível observar a paisagem das várzeas e dos arroios afluentes do 
Monografias Ambientais

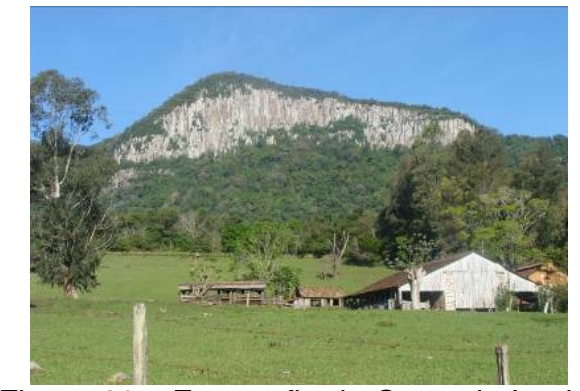

Figura 26 - Fotografia do Cerro da Igreja. Fonte: Arquivo pessoal; 22 set. 2011.

\section{USINA HIDRELÉTRICA DONA FRANCISCA}

\section{Símbolo no Mapa: UHDF}

Distância da sede: $30,0 \mathrm{~km}$

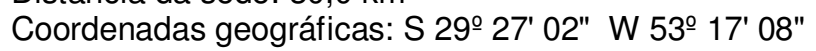

Altitude: $68 \mathrm{~m}$

A Usina Hidrelétrica Dona Francisca se localiza a 30 quilômetros do centro de Agudo, na localidade de Nova Boêmia. A Usina foi construída em 1999 e inaugurada em maio de 2001. No local de implantação da Usina, na margem direita, a Usina abrange parte dos municípios de Nova Palma e Pinhal Grande e à esquerda, Agudo, Ibarama, Estrela Velha e Arroio do Tigre, sendo a área inundada de 19,85 km².

Os objetivos da Usina são (HOPPE, 1992, p. 81).

- geração de energia elétrica 125 MW;

- regularização dos caudais e fluentes da UHE Itaúba;

- regular a vazão, reduzindo os efeitos danosos da oscilação diária da vazão do rio Jacuí;

- restabelecer o regime normal do rio, tornando possível seu pleno aproveitamento em todas as suas múltiplas potencialidades.

No caminho para a Usina, há muitos açudes, cemitérios, casas e cercas de pedra e plantações de arroz na várzea; também fazem parte do trajeto o Cerro da Igreja e a paisagem do rio Jacuí, que vai beirando a estrada até a Usina.

Para visitação em turismo técnico-científico, deve ser feita agenda com a DFSA, através do e-mail dfesa@dfesa.com.br ou pelos telefones (55) 3265.7050 (Usina) e (51) 3323.2300 (DFESA).

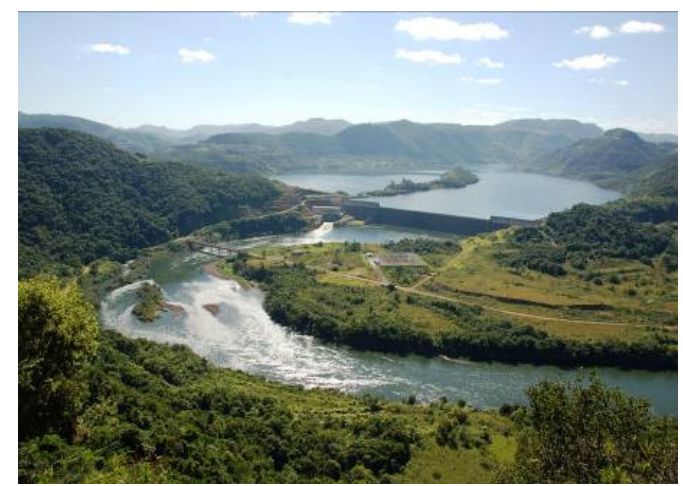

Figura 27 - Fotografia aérea da Usina Hidrelétrica Dona Francisca. Fonte: Acervo de Erni Bock; 15 mar. 2011.

$\mathrm{Na}$ área que foi atingida pela subida do rio e formação do reservatório, existiam várias manifestações culturais que, devido à crescente conscientização ambiental, foram resgatadas e preservadas para o usufruto das gerações futuras. Entre elas estavam duas casas de estilo germânico construídas em pedra ao redor de 1902 por imigrantes alemães e uma escola "brizoleta". Estes 


\section{Monografias Ambientais}

representantes do patrimônio arquitetônico histórico e cultural, graças ao novo paradigma ambiental, foram cuidadosamente reedificada pela Dona Francisca Energética. Uma das casas foi recolocada em local próximo ao acesso à Usina, preservando a história da região e funciona atualmente como recepção aos visitantes da Usina.

Outra casa germânica foi removida para o centro cívico de Agudo, tomando a função de "Casa da Cultura". A escola brizoleta está também situada atualmente no centro cívico de Agudo exercendo a função de Conselho Tutelar.

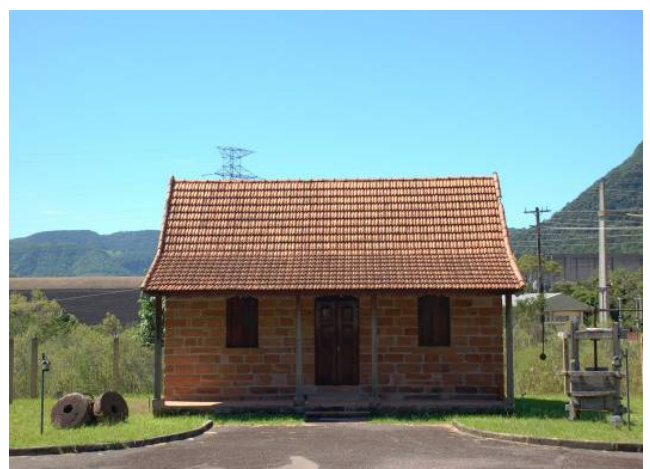

Figura 28 - Fotografia da primeira casa germânica preservada. Fonte: Acervo de Erni Böck; 15 mar. 2011.

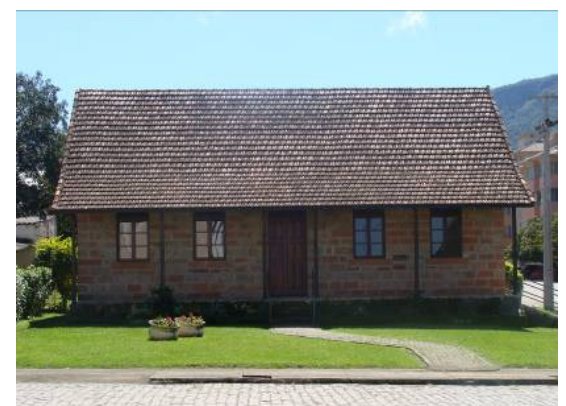

Figura 29 - Fotografia da atual "Casa da Cultura" de Agudo. Fonte: Arquivo pessoal; 27 set. 2011.

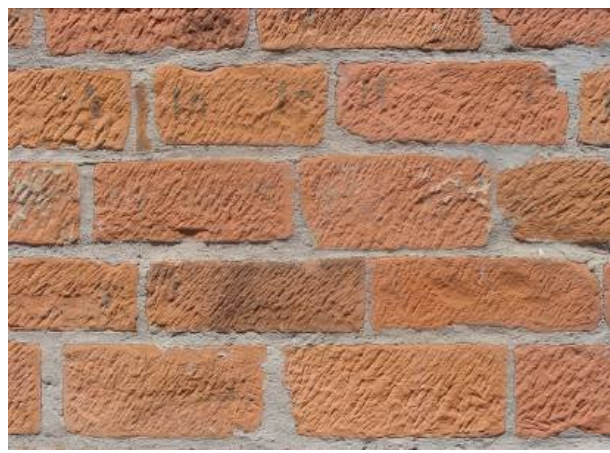




\section{Monografias Ambientais}

Figura 30 - Fotografia de detalhe da parede da Casa da Cultura de Agudo, mostrando a numeração utilizada durante o processo de reconstrução.

Fonte: Arquivo pessoal; 27 set. 2011.

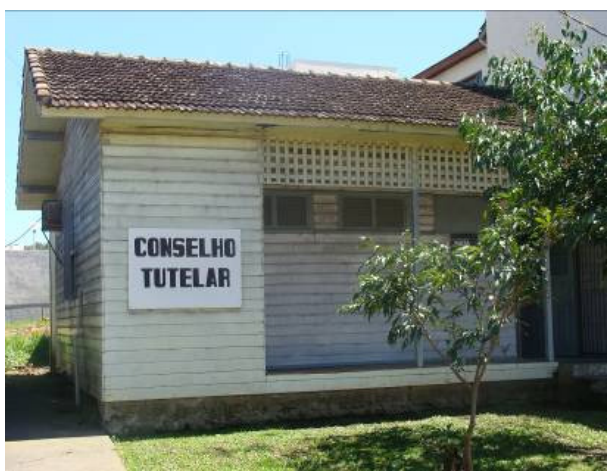

Figura 31 - Fotografia da situação atual da escola brizoleta em Agudo.

Fonte: Arquivo pessoal; 28 set. 2011.

\section{PARQUE ESTADUAL DA QUARTA COLÔNIA}

\section{Símbolo no Mapa: PEQC}

Distância da sede: Mais de 30,0 km

Altitude: $70 \mathrm{~m}$

O Parque Estadual Da Quarta Colônia foi criado em 2005, abrangendo os municípios de Agudo e Ibarama, em uma área de 1847,90 hectares.

A construção do parque é uma medida compensatória pelo impacto ambiental causado ao rio Jacuí e ao seu entorno pela construção da Usina Hidrelétrica Dona Francisca. Para isso, foi adquirido um terreno de mais 1800 hectares, entre Agudo e Ibarama, destinado ao Parque, e a faixa de entorno do lago, considerado Área de Preservação Permanente (APP). O terreno adquirido pela Usina conserva o bioma da Mata Atlântica, um dos mais impactados no Brasil, e que possui riqueza muito grande de fauna e na flora.

Com a implantação efetiva do Parque Estadual da Quarta Colônia, será possível preservar a área e, ainda, atrair visitantes interessados em ecoturismo e turismo de aventura.

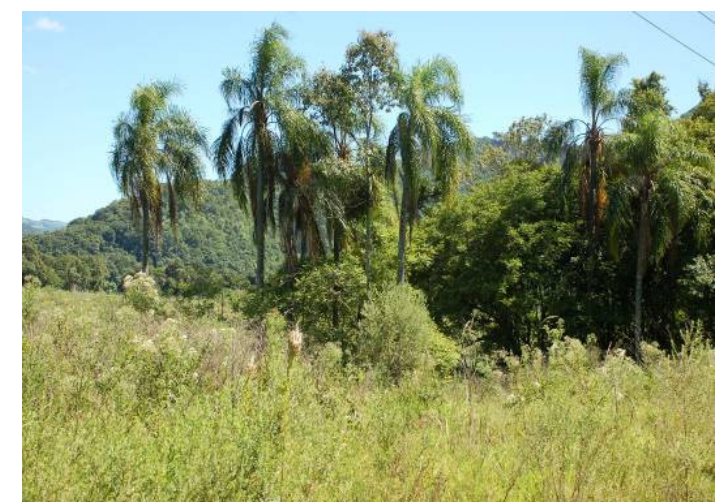

Figura 32 - Fotografia da Reserva Estadual da Quarta Colônia.

Fonte: Acervo de Erni Bock; 15 mar. 2011. 
Monografias Ambientais

Símbolo no Mapa: MF

Distância da sede: $10,0 \mathrm{~km}$

Coordenadas geográficas: S 29 41' 10" W 53ำ12' 43"

Altitude: $531 \mathrm{~m}$

O morro da Figueira, com sua forma de ferradura e os ventos favoráveis, é adequado para a prática do vôo livre (parapente e asa delta), na maior parte do ano.

Constitui uma das elevações que fazem a divisa com o município de Paraíso do Sul, distando aproximadamente 10 quilômetros da sede.

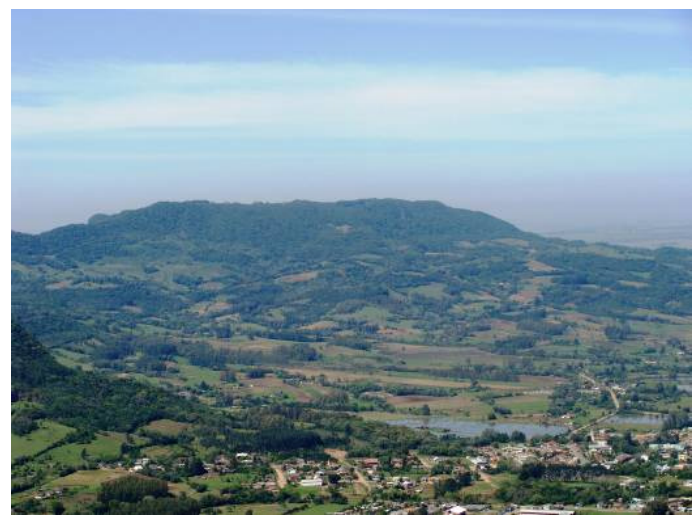

Figura 33 - Fotografia do Morro da Figueira.

Fonte: Arquivo pessoal; 27 set. 2011.

\section{ESPLANADA DO MONUMENTO}

\section{Símbolo no Mapa: EM}

Distância da sede: $6,3 \mathrm{~km}$

Coordenadas geográficas: S 29 41' 19" W 53ำ16' 05"

Altitude: $53 \mathrm{~m}$

A Esplanada do Monumento foi construída junto à ERS 348, a 6,3 quilômetros da sede, em comemoração ao Sesquicentenário da Imigração Alemã no Estado, em 2007. Simboliza a chegada dos imigrantes e toda sua vontade de construção do sonho de uma vida nova.

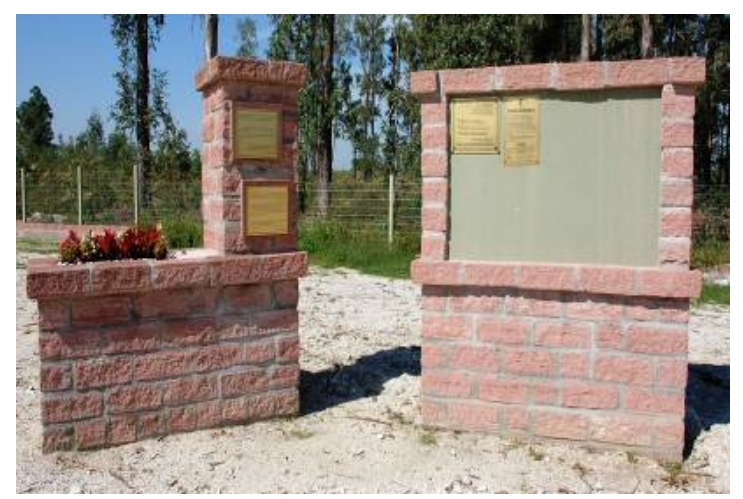

Figura 34 - Fotografia da Esplanada do Monumento. Fonte: Acervo de Erni Bock; 9 abr. 2008. 
Monografias Ambientais

(e-ISSN: 2236-1308)

REMOANFSM

CASCATA E BALNEÁRIO FRIEDRICH

Símbolo no Mapa: CBF

Distância da sede: $13,0 \mathrm{~km}$

Coordenadas geográficas: S 29 $42^{\prime}$ 31" W 53ำ 13' 37"

Altitude: $92 \mathrm{~m}$

O Balneário e Cascata Friedrich fica localizado a 1200 metros da RSC 287 e a 12 quilômetros da sede de Agudo, localidade de Rincão do Pinhal. A belíssima cascata fica nas bordas da Mata Atlântica, em local que possui plantas ornamentais nativas e exóticas, além de muita sombra e belezas naturais. Funciona durante a temporada de verão, de dezembro a março.

Possui infraestrutura de lazer em condições extremamente precárias:

"A família pretende investir e ter mais atenção com o balneário. Relatam que somente no verão possui fluxo de pessoas" (UNIFRA, 2005, p. 38).

As instalações existentes no local, área para camping, área de lazer e esportes, churrasqueiras, duas piscinas (uma natural e outra construída), banheiros, casa de recepção, cancha de bocha, trilhas, ponte de madeira, bancos de madeira para lazer e bar, estão todas necessitando adequação mínima às suas funções.

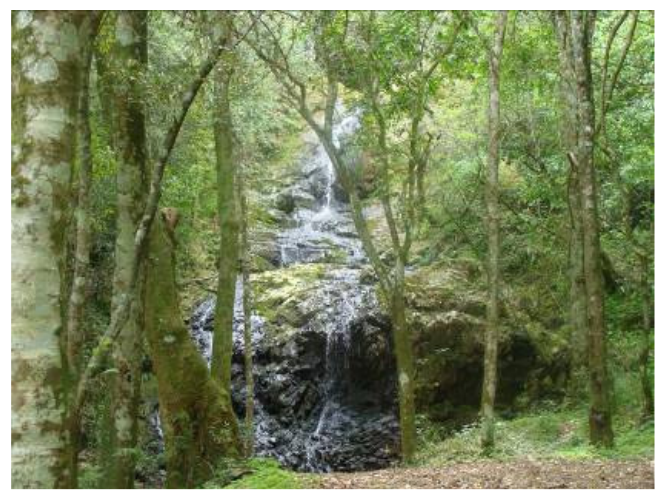

Figura 35 - Fotografia da Cascata Friedrich.

Fonte: Arquivo pessoal; 17 set. 2011.

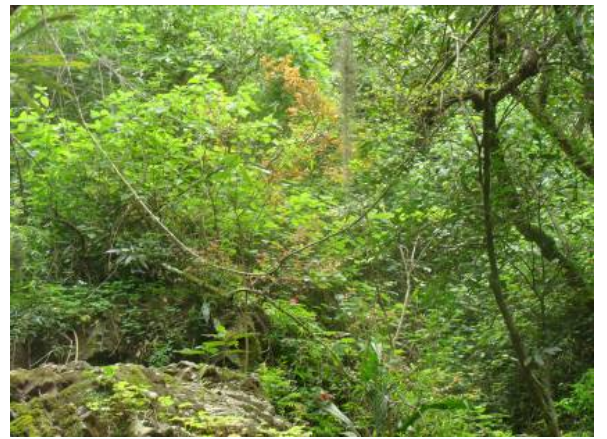

Figura 36 - Fotografia de detalhe da natureza no Balneário e da Cascata Friedrich. Fonte: Arquivo pessoal; 17 set. 2011.

\section{AÇÕES IMPLEMENTADAS NO PASSADO PELA PREFEITURA MUNICIPAL DE AGUDO}


Monografias Ambientais

(e-ISSN: 2236-1308)

REMOANFSM

Entre as diversas ações e propostas que já ocorreram no passado por iniciativa da Prefeitura Municipal de Agudo, destacam-se as registradas a seguir.

\section{ROTEIROS ECOTURÍSTICOS}

Cavalgada do Velho Casarão - a atividade que se realiza no atrativo é a cavalgada, que deve ser agendada. O ponto de saída é o velho casarão, o percurso varia de acordo com a cavalgada e a prática escolhida pelo público. Existem três opções de cavalgadas, a 1aㅡ cavalgada Velho Casarão: é um passeio numa área de 32 hectares, com árvores nativas de várias espécies, a $2^{\mathrm{a}}$ cavalgada é do Chuvisco, ou seja, é uma trilha antiguíssima, em montanhas em relevo até a cascata com trilha ecológica, onde com sorte podemos observar macacos, bugios, quatis e outros animais e a $3^{\mathrm{a}}$ cavalgada Trilhas Antigas, onde escoavam os produtos coloniais. Em seguida a Gruta dos Índios com o pico mais alto do município. $\mathrm{Na}$ chegada os turistas retornam para o velho casarão.

Rota Caminhos da Pommenn Serra - abrange a região serrana de Agudo: Linha Teutônia, Linha Nova, Complexo da Serra e Linha dos Pomeranos. E uma região do município de Agudo com características e bem próprias e distintas do resto do município. A região é a mais fria, inclusive nevando no inverno quando este é mais rigoroso, com vastas matas de araucárias, colonização germânica de origem pomerana e algumas famílias de origem italiana, estas se estabeleceram na localidade da Linha dos Pomeranos.

\section{DIVULGAÇÃO DO POTENCIAL ECOTURISTICO DO MUNICÍPIO ATRAVÉS DE FOLHETOS, FOLDERS E PUBLICAÇÕES DIVERSAS}

- Folheto referente à Cascata Raddatz (2011); Anexo B.

- Folders referentes à Quarta Colônia (2010) - Gastronomia, Cultura, Religiosidade, Roteiros Integrados e Ecoturismo.

- Inserção em revista de divulgação do município da Prefeitura Municipal (2010, p. 4) - verbete "Ecoturismo" (Anexo H)

\section{ROTEIROS \\ INTEGRADOS \\ DA \\ QUARTA \\ COLÔNIA}

Os Roteiros Integrados de Turismo Rural Cultural e Ecológico envolvem nove municípios da chamada Quarta Colônia. Os roteiros turísticos são programas dirigidos, contando, para isso, com guias treinados para orientar com eficiência o turista.

Municípios participantes: Agudo, Dona Francisca, Faxinal do Soturno, Ivorá, Nova Palma, Pinhal Grande, Restinga Seca, São João do Polêsine, Silveira Martins.

Informações: CONDESUS - Consórcio de Desenvolvimento Sustentável da Quarta Colônia - Fone: (55) 3263-1241 E-mail: condesus@com.br

\section{INSTALAÇÃO DO COMTUR E FUNTUR}

Em abril de 2011, foi dado o início das atividades do Conselho Municipal do Turismo (COMTUR) e do Fundo Municipal do Turismo (FUNTUR), através de evento ocorrido na Câmara de Vereadores com a participação de autoridades e pessoas ligadas a entidade e instituições do município.

\section{PROJETO DE GEOPARQUE - QUARTA COLÔNIA}

Foi apresentado à Secretaria do Meio Ambiente o projeto de criação do geoparque da região da Quarta Colônia que abrange os municípios de Agudo, Dona Francisca, Faxinal do Soturno, Ivorá, Nova Palma, Pinhal Grande, Restinga Seca, São João do Polêsine e Silveira Martins. 
A comunidade européia define geoparque como um território que inclui um patrimônio geológico específico e uma estratégia de desenvolvimento territorial sustentada. Deve compreender certo número de geosítios (locais de interesse geológico e paisagístico), apelo estético ou valor educativo.

O projeto vem sendo gerenciado pelo Consórcio de Desenvolvimento Sustentável da Quarta Colônia (Condesus) e vai contar com o apoio da secretaria para ser apresentado à UNESCO. Conforme o secretário executivo do Condesus/Quarta Colônia, o principal objetivo da criação do geoparque é o desenvolvimento socioeconômico da região.

O geoparque engloba o Parque Estadual da Quarta Colônia, criado pelo estado em 2005, com área de 1.847,9 hectares nos municípios de Agudo, Ibarama e Estrela Velha. Na apresentação feita ao secretário substituto José Carlos Breda e aos técnicos da secretaria, ficou clara a relevância da região sob o aspecto paleontológico. Em 1902 foram encontrados os primeiros fósseis na região e, enviados para a Europa, tornaram o RS conhecido mundialmente. Os fósseis da Quarta Colônia guardam a origem dos dinossauros e dos mamíferos. Lá foram encontrados os fósseis de quatro dos mais antigos dinossauros do mundo.

Em junho de 2011 foram iniciadas as obras do Centro de Apoio e Pesquisa Paleontológico da Quarta Colônia, em São João do Polêsine, com 2.650 metros quadrados, incluindo uma unidade museológica. O Centro conta com recursos da Petrobras e Eletrobrás.

Estão diretamente envolvidos na elaboração do projeto a Fundação Zoobotânica do RS, UFRGS, Unisinos, Universidade Federal de Santa Maria, Serviço Geológico do Brasil e Conselho Nacional da Reserva da Biosfera da Mata Attântica. Representantes dessas instituições participaram da apresentação junto com o secretário executivo do Condesus.

\section{AÇÕES E PROPOSTAS EXISTENTES FORA DA ESFERA PÚBLICA MUNICIPAL}

Entre as diversas ações e propostas que já ocorreram no passado, por iniciativa de agentes externos ao poder público do município de Agudo, destacam-se os registrados a seguir.

\subsection{ROTEIROS TURÍSTICOS PRIVADOS NA QUARTA COLÔNIA}

Cabe ressaltar que estes roteiros estão atualmente desativados.

Roteiros VIAGGIOTUR 1 - Roteiro "Vale do Jacuí" (VIAGGIOTUR, 2005, p. 3; Anexo C)

Roteiros VIAGGIOTUR 2 - Roteiro "Caminhos da Serra dos Pomeranos" (VIAGGIOTUR, 2005, p. 4; Anexo D)

\subsection{ROTEIROS TURÍSTICOS ESTADUAIS NA QUARTA COLÔNIA}

A Secretaria do Turismo Estadual (1997) instituiu o Programa "Caminhos Verdes do Rio Grande", no qual constavam dois roteiros no município de Agudo: Caminho 1 - Cascata e Gruta do Índio; Caminho 2 - Barragem (Anexo F). Igualmente, estes dois roteiros estão atualmente desativados.

\subsection{DESENVOLVIMENTO SUSTENTÁVEL DA QUARTA COLÔNIA (MACHADO, 2005, p. 130 e p. 153-} 154).

O desenvolvimento sustentável da Quarta Colônia foi proposto pela Prefeitura Municipal de Faxinal do Soturno, abrangendo nove municípios da região. $O$ objetivo era implementar ações para 0 desenvolvimento do patrimônio ambiental da Quarta Colônia e o estabelecimento de modalidades sustentáveis e inovadoras de renda, por meio de incentivo aos usos múltiplos do patrimônio cultural, manejo adequado dos recursos naturais renováveis, recuperação de áreas degradadas, enriquecimento de florestas nativas, fortalecimento de práticas de agricultura ecológica e desenvolvimento de atividades que contribuam para a preservação do patrimônio ambiental. 
A Quarta Colônia tem Nível de Atratividade 3. Ecossistema predominante: floresta ombrófila densa (Mata Atlântica). A região da Quarta Colônia apresenta características importantes para o desenvolvimento do ecoturismo, tanto nos municípios localizados próximos a Santa Maria - e que representam o quarto núcleo de imigração italiana - quanto nos municípios a oeste de Santa Maria, como Mata, Itaara e São Martinho da Serra. Situa-se no centro do Rio Grande do Sul, na região denominada Depressão Central, abrangendo os cursos médio e inferior do rio Jacuí e, junto a outros municípios, forma um rico potencial para o ecoturismo, sendo a região que apresenta os maiores depósitos fósseis do Brasil, possibilitando um diferencial através da possibilidade de desenvolvimento do turismo paleontológico.

Situada entre os vales e as encostas da região, a Quarta Colônia é composta pelos municípios de Dona Francisca, Faxinal do Soturno, Ivorá, Nova Palma, Pinhal Grande, Silveira Martins, São João do Polêsine, Restinga Seca e Agudo. O relevo apresenta-se ondulado e montanhoso, com as maiores cotas se situando ao redor de 250 e 300 metros.

A região da depressão Central é constituída, basicamente, por três degraus de vegetação.

Floresta aluvial - em áreas inundáveis e de drenagem lenta com predomínio de corticeira (Erythrina cristagall), ingá (Inga uruguensis), jerivá (Arecastrum romanzoffianum) e branquilho (Sebastiana klotzschiana), entre outras. Nas áreas esporadicamente inundáveis aparecem açoita-cavalo (Luchea dicaricata), guajuvira (Patagonula americana), camboatá (Cupania vernalis) e outros.

Floresta submontana - ocorre na vertente sul da Serra Geral, a oeste do rio Caí, estendendo-se sobre a borda do planalto das Araucárias com predomínio de grápia (Apuleia leiocarpa), angico (Parapitadenia rígida), louro (Cordia trichotoma) e outros.

Floresta Montana - floresta estacional decidual formada por pequeno número de espécies, como angico (Parapiptadenia rigida), cedro (Cedrela fissilis), canjerana (Cabralea canjerana) e outros. Essas espécies penetram na floresta ombrófila mista ao longo da borda do planalto das araucárias.

As florestas da região constituem o tipo fitogeográfico floresta estacional decidual, no qual mais de $50 \%$ dos indivíduos arbóreos do estrato superior perdem suas folhas na época de outono e inverno, formando um ecótono, uma vez que há uma interpenetração da floresta estacional decidual do alto Uruguai, da floresta ombrófila mista (mata de araucária) e da floresta ombrófila densa (Mata Atlântica), com espécies representativas das três formações. (MACHADO, 2005, p. 153).

A região se localizada no centro do estado, e sua paisagem apresenta um corredor plano, de baixa altitude, percorrido pelo rio Jacuí e seus afluentes. O rio Jacuí representa o principal curso d'água que atravessa a região, indo desaguar junto ao estuário do Guaíba, próximo a Porto Alegre. As margens baixas e planas do Jacuí e de seus afluentes apresentam áreas brejosas sujeitas a inundações periódicas. Os cursos são traçados com amplas sinuosidades e segmentos retilíneos.

Apresenta rico potencial para o turismo paleontológico, entre os municípios de Candelária e Mata, com uma das mais importantes ocorrências de fósseis do período Triássico. Nos municípios de Mata - onde há um sítio paleobotânico único no mundo - e São Pedro, ocorrem as florestas petrificadas, importantes fontes para o turismo científico.

No município de Mata, encontramos uma estrutura capaz de atender às necessidades para o pleno desenvolvimento do turismo voltado para a investigação e o conhecimento de seu rico potencial.

Os municípios que compõem a Quarta Colônia fazem parte da área piloto da Reserva da Biosfera da Mata Atlântica, sendo a sede do posto avançado localizado no município de Dona Francisca. Apresentam uma área significativa de florestas, em diferentes fases de sucessão natural, cortadas por rios e arroios com grande biodiversidade.

A principal atratividade cultural refere-se ao potencial oriundo da chegada dos imigrantes italianos, no núcleo colonial de Silveira Martins. Entre os roteiros possíveis de se realizar, citamos: o da Cascata e da Gruta do Índio, em Agudo; o da Toca da Onça, em Pinhal Grande; o das Cascatas, em Ivorá, Mata e Nova Palma; o do Cerro Cumprido, em Faxinal do Soturno; o das Pedras Brancas, em São João do Polêsine; e o do Angico, em Itaara.

\subsection{PROPOSTAS ATUAIS EM ARTIGO DE JORNAL (ROHDE, 2010)}

Rohde (2010), em artigo publicado em veículo impresso de grande circulação em Agudo, apresenta as seguintes propostas que possuem vínculo direto com o ecoturismo; a numeração está de acordo com o artigo original, faltando os números que não possuem ligação direta com a temática ecoturística. 


\section{PROPOSTA 1 - "Agudo Spitzberg"}

Procurar/localizar e contatar uma "cidade-irmã" na Alemanha; potencializar a germanidade já existente no município, na cidade e nos arredores-região de Agudo, através de convênios ou projetos.

\section{PROPOSTA 3 - Ciclovias em Agudo e arredores}

Criar o sistema de ciclovias do município, podendo ter como referência os municípios de Sapiranga, Ivoti e Novo Hamburgo, por exemplo.

\section{PROPOSTA 5 - Colocar Agudo como um Centro de Ecoturismo}

Potencializar as suas imensas belezas naturais, cênicas, rurais e culturais (arquitetura, história, estatutária fúnebre, patrimônio da imigração) através de ação focada no ecoturismo, mas com eixos transversais para o turismo rural, turismo hidroviário, gastronômico, etc. Utilizar o conceito de educação ambiental como vetor do ecoturismo, conforme proposto pela administradora Marlisa Marlene Strenzel neste mesmo jornal.

\section{PROPOSTA 6 - Criar uma rede municipal de trilhas ecológicas}

Decorrente da proposta 5, ligar os pontos de beleza natural, cênica, arquitetônica, patrimonial, etc. através de uma rede de trilhas (em diferentes níveis de dificuldade) e construir pinguelas/pontes rústicas sobre os arroios a serem cruzados por elas.

PROPOSTA 8 - Construir a "Casa de Agudo" junto ao pórtico de entrada da cidade junto à rodovia RSC-287 para Promover os Arranjos Produtivos Locais-APLs.

Este quiosque ofereceria artesanato, produtos coloniais/imigracionais e turísticos, além de promover as ações de educação ambiental quanto ao Ecoturismo. A construção teria igualmente a função de recepção de turistas e autoridades que iniciassem visita à cidade e ao interior de Agudo.

PROPOSTA 9 - Criação do Fundo de Valorização Intelectual de Agudo

Este fundo teria dois objetivos: (1) realizar ação proativa e efetiva no sentido de publicar os escritos originais feitos sobre (e em) Agudo, valorizando o trabalho intelectual de pessoas do município; e (2) promover, através da Secretarias de Educação e Cultura, a publicação de um livro anual, contendo trabalhos escritos pelas crianças de Agudo, escolhidos pelos professores e pelos próprios alunos (colegas entre si).

PROPOSTA 10 - Promover/proporcionar cursos, com atenção para a diversidade de faixa etária, necessidade social e condição sócio-econômica

Estes cursos incluiriam capacitações em ecoturismo, monitoria de trilhas ecológicas, turismo rural, gastronomia e culinária, artesanato, corte e costura, tricô-crochê, pintura em tecido e cerâmica, pintura artística, arranjos para festas, gravação em vidro, pirogravura, etc.

\subsection{OUTRA PROPOSTA EXISTENTE ATUALMENTE}

Há a ideia de que deva existir, junto à rótula de entrada de Agudo, um marco de referência regional e estadual que identifique o município como o berço de uma indústria nacional de escala mundial - o Grupo Gerdau.

\section{EDUCAÇÃO AMBIENTAL COMO VETOR DE ECOTURISMO}

A educação ambiental é sempre apontada como uma alternativa à educação clássica, fragmentada e desconectada do meio ambiente. A partir do conhecimento da questão ambiental e de uma sensibilidade ecológica, existe uma conscientização-percepção que instaura aptidões e atitudes que vão dar origem a 
ações ambientalmente responsáveis. O agir ambiental inicia uma cidadania que promove a responsabilidade local e global: "Pense globalmente e aja localmente", segundo o clássico ditado ambiental. 1996).

A principal função da educação ambiental é, portanto, a promoção de uma ética ambiental (GRÜN,

O nexo existente entre Educação Ambiental e ecoturismo é abordado por Strenzel (2010), em artigo intitulado "Meio Ambiente, Educação Ambiental e Ecoturismo em Agudo" (Apêndice A).

Para tentar sanar as lacunas da educação formal clássica, a educação ambiental tenta informar, conscientizar e sensibilizar as pessoas em suas atitudes e, ao final, de sua responsabilidade ética para com o ambiente em que vivem. Na ausência de uma conscientização, através da educação ambiental, existem vários impactos ambientais e sociais que podem advir do turismo e, até mesmo, do ecoturismo (Quadro 6).

Quadro 6 - Impactos decorrentes do turismo e ecoturismo sem postura ética ambiental (MACHADO, 2005, p. 94).

\begin{tabular}{|c|c|c|}
\hline FATOR DE IMPACTO & EFEITO & IMPACTO \\
\hline Afluência excessiva & $\begin{array}{l}\text { Pisoteio, mudança na conduta animal, } \\
\text { compactação do solo }\end{array}$ & Irritação da fauna \\
\hline Trilhas & $\begin{array}{l}\text { Perturbação da fauna, remoção da } \\
\text { cobertura vegetal }\end{array}$ & Erosão das pistas \\
\hline Ruídos & Perturbação de sons naturais & $\begin{array}{l}\text { Estresse na fauna, irritação do } \\
\text { visitante }\end{array}$ \\
\hline Lixo & $\begin{array}{l}\text { Degradação da paisagem, mudança } \\
\text { comportamental da fauna }\end{array}$ & $\begin{array}{l}\text { Dependência da fauna } \\
\text { contaminação do solo e água }\end{array}$ \\
\hline Vandalismo & $\begin{array}{l}\text { Destruição de instalações remoção de } \\
\text { atrativos naturais }\end{array}$ & $\begin{array}{l}\text { Redução da qualidade estética } \\
\text { e danos materiais }\end{array}$ \\
\hline Excesso de veículos & $\begin{array}{l}\text { Liberação de gases, degradação do } \\
\text { solo }\end{array}$ & $\begin{array}{l}\text { Deterioração da qualidade do } \\
\text { ar, mudanças ecológicas }\end{array}$ \\
\hline $\begin{array}{lll}\text { Introdução de } & \text { plantas } & \text { e } \\
\text { animais exóticos } & & \end{array}$ & Confusão no público & $\begin{array}{lll}\begin{array}{l}\text { Competição } \\
\text { nativas }\end{array} & \text { com } & \text { espécies } \\
\end{array}$ \\
\hline Construção de instalações & $\begin{array}{l}\text { Remoção da cobertura vegetal, } \\
\text { eliminação de hábitat }\end{array}$ & $\begin{array}{l}\text { Aumento da sensibilidade à } \\
\text { erosão, danos estéticos }\end{array}$ \\
\hline
\end{tabular}

A atuação do poder público e das instituições de ensino com relação à educação ambiental ligada ao ecoturismo serão sempre no sentido de:

1 - ampla divulgação em campanhas permanentes de informação sobre ética e práticas de mínimo impacto ambiental e social;

2 - a adoção de instrumentos de educação e manejo que contribuam para a minimização dos impactos.

Tendo em vista que o município de Agudo possui uma imensa potencialidade ecoturística, em função do patrimônio natural (paisagens, morros, cerros, rio, cascatas, caverna, flora e fauna) e culturais (arquitetura, folclore, estatutária e poesia fúnebre, eventos culturais e artísticos) e que é - ainda amplamente subutilizada, torna-se necessário que haja uma conexão entre o ecoturismo e a educação ambiental.

Assim, a ampliação correta e sustentável do Ecoturismo deve, portanto, ser realizada a partir de ações originadas dos princípios da educação ambiental. "A Educação Ambiental, nas suas diferentes formas, abordagens e estratégias pode constituir ferramenta para Agudo desenvolver o seu potencial ecoturístico" (STRENZEL, 2010).

A aplicação da educação ambiental ao ecoturismo tem de ser realizada de duas maneiras: (1) a conscientização dos habitantes de Agudo sobre seu patrimônio ambiental e (2) a necessidade de sua preservação visando à sustentabilidade e as informações corretas a serem divulgadas aos turistas, 
visitantes e outros passantes quanto ao respeito e usufruto do patrimônio natural e cultural que lhes é apresentado.

Estas duas ações precisam ser baseadas e implementadas nas duas formas da educação ambiental, a formal e a informal. A educação ambiental formal nos seus diferentes níveis proporcionará a crianças, jovens, adultos e terceira idade uma conscientização maior sobre preservação ambiental e sustentabilidade de seu patrimônio e a informal orientará os turistas, viajantes e passantes quanto à percepção do contexto natural e cultural e ao respeito do patrimônio. Para tanto, estabeleceu-se uma tentativa de "Código de conduta dos ecoturistas em Agudo" (Apêndice B).

A potencialidade ecoturística do Município de Agudo necessita de uma ação sistemática e continuada do poder público na esfera educacional e turística, que leve à sua plena conscientização e uso.

\section{CONCLUSÕES E RECOMENDAÇÕES}

\section{1 Conclusões}

A partir dos dados secundários obtidos através de pesquisa na Internet, em livros, relatórios, revistas, materiais de divulgação públicos e privados, de dados primários de pesquisas já existentes, e pela corroboração em trabalho de campo, torna-se possível estabelecer as conclusões registradas a seguir:

- apesar do extraordinário potencial ecoturístico do município de Agudo, não existe ainda uma apropriação pública ou privada no sentido de efetivar o seu uso;

- conforme depreendem os dados exibidos no volume I do Inventário da Oferta Turística do Município de Agudo/RS (UNIFRA, 2005) o próprio município não divulga e nem incentiva os visitantes de seus grandes eventos a visitar os pontos ecoturísticos;

- a partir dos relatos existentes no volume II do Inventário da Oferta Turística do Município de Agudo/RS (UNIFRA, 2005), o comércio local não costuma divulgar os pontos turísticos aos seus clientes; não mantém informações sobre áreas naturais de interesse turístico e nem incentiva seus clientes à visitação;

- pela observação dos formulários 7, 11 e 12 do volume II do Inventário da Oferta Turística do Município de Agudo/RS (UNIFRA, 2005), as organizações não participam ou apóiam a manutenção e manejo de áreas protegidas - estatais ou privadas;

- o volume I do Inventário da Oferta Turística do Município de Agudo/RS (UNIFRA, 2005) aponta igualmente para uma série de deficiências, falhas, lacunas e precariedades, tais como má sinalização geral, inexistência de sinalização turística, inexistência de transporte até os locais dos atrativos, inexistência de legislação de proteção aos atrativos;

- as tentativas públicas e privadas já feitas, implementadas, propostas e iniciadas no passado, encontramse todas esquecidas, desativadas e abandonadas, sem efeito prático na atualidade;

- excetuando-se o turismo de eventos, notadamente a "Ein Volksfest in Agudo" (sempre em julho), o Choculin (realizado em fevereiro/março) e a "Festa do Moranguinho e da Cuca", o segmento "turismo" se iguala ao ecoturismo, pois o potencial turístico do município recai, na sua quase totalidade, em atrativos, belezas e locais que tem fundamento nos recursos naturais e acidentes geográficos; mesmo os monumentos de interesse histórico, artístico e arquitetônico estão imersos na imensidão da paisagem agudense, marcada pelos morros, pela mata atlântica e pela exuberante biodiversidade do município;

- há um vazio na atuação do poder público quanto ao ecoturismo no município, que se manifesta no abandono de iniciativas preexistentes e no quadro atual de carência total de produtos viáveis do ponto de vista coletivo ou mesmo por parte da iniciativa privada, que igualmente abandonou o setor pelas carências e descontinuidades já descritas. 


\section{2 Recomendações}

A partir dos dados secundários obtidos através de pesquisa na Internet, em livros, relatórios, revistas, materiais de divulgação públicos e privados, de dados primários de pesquisas já existentes, e pela corroboração em trabalho de campo, das conclusões extraídas e já apresentadas, torna-se possível fornecer as seguintes recomendações:

- urge o Poder Público de Agudo implementar uma política clara, transparente e bem definida sobre turismo e o seu segmento mais interessante para o município, que se constitui no ecoturismo;

- o Poder Público de Agudo tem de implementar uma política baseada na transversalidade em relação à atuação das suas secretarias, com a consciência clara de que o ecoturismo traz benefícios significativos para o município (SOIFER, 2005, p. 2), tais como: diversificação da economia, através da indução à geração de micro e pequenos empreendimentos; geração de empregos; fixação da população no meio rural; melhoramento das infraestruturas de transporte, comunicação e saneamento; criação de alternativas de arrecadação para as Unidades de Conservação; diminuição do impacto sobre patrimônio natural e cultural e estético-paisagístico e melhoria nos equipamentos nas áreas protegidas;

- é imprescindível que seja executado um mapa dos pontos de ecoturismo de Agudo, em linguagem acessível para divulgação aos habitantes do município, aos alunos de escolas públicas e privadas (através da Educação Ambiental) e aos turistas que o visitam;

- é necessário que a sinalização de localização (placas localizadoras), de acesso (placas indicativas) e descrição (placas explicativas) dos pontos de interesse ecoturístico seja feita de forma adequada a orientar os turistas; os pontos ecoturísticos devem também receber melhor comunicação visual e sinalização nas redondezas em que se encontram; deve, igualmente, ser providenciada sinalização descritiva no local em que se situam os atrativos ecoturísticos;

- deve ser providenciada uma lista informativa, baseada em critérios que educação ambiental e sustentabilidade, sobre a forma de proceder e agir nos ambientais naturais que o turista irá visitar (Apêndice B).

\section{REFERÊNCIAS}

BARROS, Maria Isabel Amando de; DINES, Milton. Mínimo impacto em áreas naturais uma mudança de atitude. In: SERRANO, Célia (Org.). A educação pelas pedras : Ecoturismo e educação ambiental. São Paulo: Chronos, 2000. p. 47-84.

COSTA, Patrícia Côrtes. 2. Ed. Ecoturismo. São Paulo: Aleph, 2005. 94 p., il.

DELGADO, Jesus. A interpretação ambiental como instrumento para o ecoturismo. In: SERRANO, Célia (Org.). A educação pelas pedras: Ecoturismo e educação ambiental. São Paulo: Chronos, 2000. p. 155169.

FACCHIN, Odilia. 3. Ed. Fundamentos de metodologia. São Paulo: Saraiva, 2001.

FARIAS, Daiane Sündermann. Ein Volksfest in Agudo: Etnografia da "Festa do Povo em Agudo". Santa Maria: UFSM, 2010. 64 p.,il. (Monografia de Graduação em Ciências Sociais).

FENNELL, David A. Ecoturismo: Uma introdução. São Paulo: Contexto, 2002. 281 p., il.

FROEHLICH, José Marcos; ALVES, Heberton F. Inocêncio. Novas Identidades, Novos Territórios Mobilizando os Recursos Culturais para o Desenvolvimento Territorial. Revista Extensão Rural, Santa Maria, v. 14, jan.-dez. 2007.

GRÜN, Mauro. Ética e Educação Ambiental: A Conexão Necessária. Campinas: Papirus,1996. 120 p. 
Monografias Ambientais

(e-ISSN: 2236-1308)

HOPPE, Leani Dânia Schumacher. (Coord.) Conhecendo Agudo-RS. Agudo: SMEC, 1992. 97 p., il.

HOUAISS, Antônio; VILLAR, Mauro de Salles. Dicionário Houaiss da Língua Portuguesa. Rio de Janeiro: Objetiva, 2009. 1986 p., acompanhado de CD-ROM.

ITAQUI, José (Org.). Quarta Colônia - Inventários Técnicos. Santa Maria: Pallotti, 2002. 256 p., il.

KOTLER, Philip. Administração de Marketing. 5. Ed. São Paulo: Atlas, 1998.

MARCHI, Salette; SUPTITZ, Carla. Roteiros Integrados de Turismo Rural, Cultural e Ecológico: Quarta Colônia de Imigração Italiana RS. Santa Maria: Pallotti, 1996. 12 p., il.

MACHADO, Álvaro. Ecoturismo - Um Produto Viável: A experiência do Rio Grande do Sul. Rio de Janeiro, 2005. 232 p., il.

MÜLLER, Jackson. Educação Ambiental: Diretrizes para a Prática Pedagógica. Porto Alegre: Nova Prova/FAMURS, [1994]. 146 p., il.

PREFEITURA MUNICIPAL DE AGUDO. Agudo/RS. Agudo: Arte Impressa, 2010. 10 p., il.

ROHDE, Geraldo Mario. Propostas para Agudo ser o polo geopolítico no centro do Estado. Deutsche Integration, Restinga Seca, v. 10, n. 544, Caderno Variedades p. 1, 3-9 set. 2010.

SECRETARIA DO TURISMO. ESTADO DO RIO GRANDE DO SUL. Caminhos Verdes do Rio Grande: Corredores de Ecoturismo da Região Central. Porto Alegre, 1997.

SOIFER, Jack. Empreender Turismo e Ecoturismo. Rio de Janeiro: Qualitymark, 2005. 158 p., il.

STRENZEL, Marlisa Marlene. Meio Ambiente, Educação Ambiental e Ecoturismo em Agudo. Deutsche Integration, Restinga Seca, v. 9, n. 535, Caderno Variedades p. 1, 2-8 jul. 2010.

SWARBROOKE, John. Turismo Sustentável: Turismo Cultural, Ecoturismo e Ética. São Paulo: Aleph, 2000. 135 p., il. (Série Turismo v. 5).

UNIFRA. Inventário da Oferta Turística do Município de Agudo / RS. Santa Maria: UNIFRA, 2005. v. 1(p. 1-145); v. 2 (p. 146-322).

VERGARA, Sylvia C. 3. Ed. Projetos e Relatórios de Pesquisa em Administração. São Paulo: Atlas, 2000.

VIAGGIOTUR. Roteiros Turísticos da Quarta Colônia. Faxinal do Soturno: Viaggiotur/SEBRAE, 2005. 16 p., il.

WERLANG, William. Colônia Santo Ângelo (1857-1890). Santa Maria: Pallotti, 1991. 128 p., il.

WERLANG, William. História da Colônia Santo Ângelo. Santa Maria: Pallotti, 1995. v. 1. 288 p., il. 